Linköping Studies in Science and Technology

Dissertation No. 1701

\title{
Electronic properties of intrinsic defects and impurities in $\mathrm{GaN}$
}

Tran Thien Duc

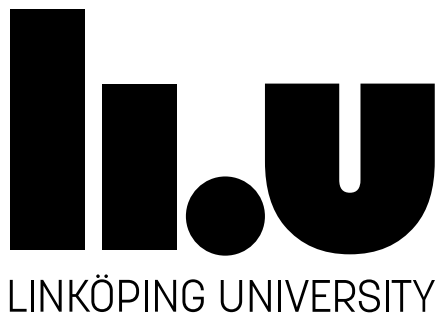

Semiconductor Materials Division

Department of Physics, Chemistry, and Biology (IFM) Linköping University, SE-581 83 Linköping, Sweden Linköping 2015 
(C) Tran Thien Duc, 2015

Printed in Sweden by LiU-Tryck 2015

ISSN 0345-7524

ISBN 978-91-7685-950-6

ii 


\begin{abstract}
With its outstanding properties such as a wide direct bandgap (3.4 $\mathrm{eV}$ ), high electron mobility and high breakdown voltage, GaN and its alloys with In and $\mathrm{Al}$ are considered as one of the most important semiconductors for optoelectronic devices (ultra-violet lasers, lightemitting diodes (LEDs) in a short-wavelength region), high-power and high-frequency devices (high electron mobility transistors, switches). The most important application of GaN today is high-brightness blue LEDs, which can be used in many areas. With the discovery of GaNbased blue LED, Isamu Akasaki, Hiroshi Amano and Shuji Nakamura were awarded the Nobel Prize in 2014.
\end{abstract}

Defects in material are important since they influence the electronic properties of $\mathrm{GaN}$ and depending on the origin, we can classify them as intrinsic defects or impurities. An impurity is one or several foreign atoms in the host crystal while an intrinsic defect is an imperfection in the host's crystal lattice. The presence of defects may give rise to energy levels in the bandgap that may trap electrons or holes. Depending on how the trapped carriers are localized to the defect, we classify them as deep or shallow levels. Shallow levels have a long ranged potential, where a trapped carrier is relatively weakly bounded to the defect while deep levels have a short ranged potential where a trapped carrier is strongly bounded. In principle, these levels can affect GaN-based devices in the both negative and positive ways. Therefore, it is necessary to understand and to identify the properties of defects to be able to predict their influence on the behavior of devices, and thereby, optimize the performance of the device for its application. Normally, defects can be introduced either intentionally or unintentionally into semiconductors during the growth process, during processing of the device or from the working environment. Especially for $\mathrm{GaN}$, due to the lack of native substrates, most of the GaN-based device structures are fabricated on a foreign substrates such as silicon carbide $(\mathrm{SiC})$ or sapphire $\left(\mathrm{Al}_{2} \mathrm{O}_{3}\right)$. Growth on foreign substrates gives rise to high threading dislocation densities, and they can give rise to deep levels that influence the performance of the device.

In order to study defects and to understand their origin, it is common to intentionally introduce them by electron irradiation. By 
varying the electron-beam energy and fluence, we can judge their nature. The most powerful and commonly used technique for studying electronic properties of deep levels in semiconductors is deep level transient spectroscopy (DLTS) which was invented by D.V. Lang in 1974. This technique bases on the observation of the capacitance transient caused by the thermal emission process of charge carriers from deep levels. The advantage of this technique is that it is simple to obtain important information of defects such as activation energy, capture-cross section, defect concentration and depth profile of defects. In DLTS technique using Schottky diodes, one normally observes deep levels related to trapping of majority charge carriers. To characterize minority carrier traps, another method, named minority charge carrier transient spectroscopy (MCTS) is commonly used. Other important measurement techniques for electrical characterization of defects are current-voltage measurements (IV), capacitance-voltage measurements (CV) and Hall measurements.

This thesis is focused on electrical characterization of intrinsic defects and impurities in GaN grown by halide vapor phase epitaxy (HVPE) and metalorganic vapor phase epitaxy (MOCVD). In addition, the present study has investigated how efficiently defects are introduced in GaN by electron irradiation. Paper $\mathbf{1}$ is focused on electrical characterization of intrinsic defects in freestanding HVPE grown GaN. Six electron traps were detected, where two of them were introduced by the polishing process. For three of the traps, the temperature dependence of the electron capture cross section was studied. From their electron capture properties, it was suggested that the traps are associated with point defects. Paper 2 investigates electron and hole traps in $\mathrm{Mg}$-doped $\mathrm{GaN}$ grown by MOCVD on thick HVPE grown GaN. One hole trap of high concentration was detected in the Mg-doped layer by MCTS. It was observed that the hole emission rate was enhanced by increasing electric field suggesting the Poole-Frenkel effect. The field emission enhancement was compared with several theoretical models. In Paper 3-6, intrinsic defects in GaN introduced intentionally by electron irradiation with different fluences have been studied. Paper 3 discusses electron-irradiation-induced defects in bulk GaN grown by HVPE and the annealing behavior of the defects. Three electron-irradiation-induced traps were detected after $2 \mathrm{MeV}$ electron irradiation at a fluence of $1 \times 10^{14} \mathrm{~cm}^{2}$. Due to 
the annealing behavior, two of the levels were suggested to be related to primary intrinsic defects. In Paper 4, the temperature dependence of the electron capture cross sections for three levels in electronirradiated $\mathrm{GaN}$ was studied. The temperature dependence of one of them showed that the electron capturing is governed by a cascade capturing process whereas no temperature dependence was observed for the other levels. In Paper 5, a detailed study of the thermal stability of defects in $\mathrm{GaN}$ after $2 \mathrm{MeV}$ electron irradiation was performed. Isochronal annealing shows that most of the defects annealed out already at $550 \mathrm{~K}$ and using isothermal annealing the activation energy of the process was determined. Hole traps in $2 \mathrm{MeV}$ n-type electron irradiated GaN were studied by MCTS in Paper 6. The hole and electron trap concentration and activation energies for three levels have been determined. From the dependence of the defect concentration on the electron irradiation fluence, the defect introduction rate was extracted. 


\section{Populärvetenskaplig sammanfattning}

Halvledarmaterialet galliumnitrid $(\mathrm{GaN})$ och dess legeringar med indium (In) och aluminium (Al) betraktas idag som ett av de viktigaste materialen för framställning av nya energieffektivare optoelektroniska, hög effekt och hög frekvens komponenter. Den största och viktigaste tillämpningen av GaN är energieffektiva LED lampor som idag ersätter traditionella glödlampor. Upptäckterna som gjorde det möjligt att framställa GaN baserade LED belönades med Nobelpriset 2014 som gick till Isamu Akasaki, Hiroshi Amano och Shuji Nakamura.

För att det ska vara möjligt att använda GaN för framställning av komponenter krävs det att man har grundläggande kunskaper om materialets optiska och elektriska egenskaper. En viktig egenskap hos $\mathrm{GaN}$ och andra halvledare är att man kan kontrollera materialets konduktivitet genom så kallad dopning. När man dopar en halvledare tillsätter man små mängder föroreningar, så kallade störämnen. Beroende på störämne kan de bidra med extra elektroner (donatorer) eller binda elektroner (acceptorer). När de binder en elektron blir det en avsaknad av en elektron, kallat också ett hål. Hålen och elektronerna kan röra på sig i kristallen och om de möts kan energi frigöras genom att utsända ljus eller skapa vibrationer hos omgivande atomer. För att elektroner ska frigöra sig från störatomerna eller att hålet ska kunna bildas krävs det energi till exempel från värme eller ljus. Beroende på om störämnet kräver lite eller mycket energi brukar man klassificera de i något som vi kallar grunda eller djupa nivåer. Störämnen med grunda nivåer, som kräver lite energi, är önskvärda om man ska dopa kristallen eftersom hål eller elektroner är rörliga redan vid rumstemperatur. I fallet $\mathrm{GaN}$ används $\mathrm{i}$ huvudsak magnesium $(\mathrm{Mg})$ för håldopning och kisel $(\mathrm{Si})$ för elektrondopning. Störämnen med djupa nivåer kan fånga in elektroner eller hål vilket kan ge en icke önskvärd påverkan på materialets egenskaper. Dock kan djupa nivåer vara användbara om man vill framställa hög-resistivt material. Beroende på om en djup nivå fångar in en elektron eller ett hål så brukar man skilja på de som elektronfällor eller hålfällor.

Det finns även andra orsaker till att fällor kan bildas i kristallen. En perfekt GaN kristall består endast av Ga och $\mathrm{N}$ atomer, där alla atomer 
är ordnande i ett så kallat periodiskt gitter. Perfekt kristaller existerar inte. Exempelvis kan någon eller flera atomer saknas i gittret, atomer är inte inordnade i gittret eller atomer har bytt plats. Denna typ av fel i kristallen brukar benämnas intrinsiska defekter och precis som hos störämnen så kan de bilda fällor vilket påverkar materialet elektriska och optiska egenskaper. Intrinsiska defekter kan skapas och föroreningar kan föras in i $\mathrm{GaN}$ kristallen antingen avsiktligt eller oavsiktligt under syntetiseringen av kristallen, under framställningen av komponenten, eller från omgivningen. Följaktligen krävs det att man har en god kontroll på materialets renhet och kristallina kvalité samt att man kan kontrollera och har förståelse om hur föroreningar och intrinsiska defekter i kristallen påverkar materialets elektriska och optiska egenskaper.

I denna avhandling har djupa nivåer i GaN och elektronbestrålad $\mathrm{GaN}$ studerats. Elektronbestrålning är en teknik som används för att skapa intrinsiska defekter vilket underlättar studier av dessa samt att man kan få kännedom om defekters ursprung. De defekter som har studerats i denna avhandling är elektriskt aktiva och har studerats $\mathrm{i}$ huvudsak med hjälp av karakteriseringsteknikerna deep level transient spectroscopy (DLTS) och minority carrier transient spectroscopy (MCTS). För att använda sig av DLTS och MCTS teknikerna krävs det enklare komponentstrukturer, så kallade Schottky dioder eller pndioder. I den första delen av avhandlingen studeras defekter som har skapats under syntetiseringen av GaN materialet med hjälp av halogen gas fas epitaxi (HVPE), under polering samt defekter relaterade till Mg-dopad GaN syntetiserad med metalorganic chemical vapour deposition (MOCVD). I den andra delen har intrinsiska defekter i elektron bestrålat GaN studerats. I DLTS undersökningar av $\mathrm{GaN}$ syntetiserad med hjälp av HVPE observerades sex elektron fällor där två av dem var relaterade till poleringsprocessen. För att förstå elektroninfångningsprocesserna så undersöktes temperaturberoendet hos elektroninfångningstvärsnittet för tre av defekterna. Från elektroninfångningsmätningarna noterades att fällorna är relaterade till punktdefekter. I det andra pappret har Mg-dopat GaN syntetiserat med MOCVD studerats med hjälp av MCTS. Ur mätningen detekterades höga koncentrationer av en hålfälla. Genom att öka det elektriska fältet, så ökade hål emissionshastigheten från defekten. Det är en egenskap som är relaterad till den så kallade Poole-Frenkel 
effekten samt phonon assisterad tunneling och beror på hur bindningspotentialen ändrar utseende med det elektriska fältet. Teoretiska modeller för Poole-Frenkel effekten och phonon assisterad tunneling jämfördes med de experimentella resultaten.

För att kunna särskilja mellan intrinsiska defekter och föroreningar undersöktes elektron bestrålat material samt hur värmebehandling påverkar dem. Tre elektronfällor observerades efter bestrålning med 2 $\mathrm{MeV}$ elektroner, och dosen $1 \times 10^{14} \mathrm{~cm}^{2}$. På grund av hur koncentrationen av defekter ändrades vid värmebehandling samt den höga koncentrationen efter bestrålning så föreslås det att två av elektronfällorna är relaterade till primära intrinsiska defekter. Genom att bestråla materialet med en betydligt högre dos $\left(5 \times 10^{16} \mathrm{~cm}^{2}\right)$ observerades ytterligare nivåer. Efter värmebehandling vid $650 \mathrm{~K}$ minskade koncentrationen av defekter drastiskt. Temperaturberoendet hos elektroninfångningstvärsnittet undersöktes för tre av fällorna och en av de uppvisade ett temperaturberoende som är typiskt för en så kallad kaskad infångningsprocess. Den termiska stabiliteten hos defekter efter $2 \mathrm{MeV}$ elektron bestrålning undersöktes i detalj med hjälp av en värmebehandlings studie. Värmebehandlingen visar att de allra flesta defekterna försvinner redan vid $550 \mathrm{~K}$. Från studien bestämdes även den termiska aktiveringsenergin som krävs för att en av defekterna ska försvinna. En djupa hål fälla samt en elektron fälla $\mathrm{i}$ $2 \mathrm{MeV}$ elektron bestrålad GaN studerades med MCTS. Fällornas koncentrationer och aktiveringsenergier bestämdes. Från hur koncentrationen av fällor beror på strålningsdosen så kunde relationen mellan strålningsdos och defektkoncentration bestämmas. 


\section{PREFACE}

This Doctoral Thesis is a result of four and a half years' work during my $\mathrm{Ph} . \mathrm{D}$ studies in Semiconductor Materials group at Linköping University. The project was financed by Swedish Energy Agency and the Swedish Research Council (VR). The results are presented in six included papers preceded by the introduction.

Linköping, September 2015 


\section{INCLUDED PAPER}

1. Investigation of deep levels in bulk GaN material grown by halide vapor phase epitaxy

T.T. Duc, G. Pozina, E. Janzén, and C. Hemmingsson

J. Appl. Phys. 114, 153702 (2013).

2. Deep level study of Mg-doped GaN using deep level transient spectroscopy and minority carrier transient spectroscopy

T.T. Duc, G. Pozina, H. Amano, E. Janzén, and C. Hemmingsson. In manuscript.

3. Radiation-induced defects in GaN bulk grown by halide vapor phase epitaxy

T.T. Duc, G. Pozina, N.T. Son, E. Janzén, T. Ohshima and C. Hemmingsson, Appl. Phys. Lett. 105, 102103 (2014).

4. Electronic properties of defects in high-fluence electron irradiated bulk GaN

T.T. Duc, G. Pozina, N.T. Son, E. Janzén, T. Ohshima and C. Hemmingsson, Submitted to Physica Status Solidi (b).

5. Thermal behavior of irradiation-induced-deep level in bulk GaN

T.T. Duc, G. Pozina, N.T. Son, E. Janzén, O. Kordina, T. Ohshima and C. Hemmingsson, In manuscript.

6. Deep levels in as-grown and electron-irradiated n-GaN studied by deep level transient spectroscopy and minority carrier transient spectroscopy

T.T. Duc, G. Pozina, N.T. Son, E. Janzén, O. Kordina, T. Ohshima and C. Hemmingsson, In manuscript.

My contribution to the papers: I performed all electrical characterizations, wrote draft of the manuscripts and discussed results and models with other co-authors. 


\section{Acknowledgements}

I would like to show my gratitude to all the people who supported and encouraged me during the time of working and writing this thesis.

- Assoc. Prof. Carl Hemmingsson - my main supervisor. I would like to thank my supervisor for giving me the opportunity of studying as $\mathrm{PhD}$ in Linköping. I appreciate the time he took to share his knowledge and experience, which helped me to learn a lot of useful things for my future work.

- Assoc. Prof. Galia Pozina - my co-supervisor for always helping me to improve all my papers and giving me lots of valuable comments.

- Prof. Erik Janzén - my co-supervisor, who always supported and gave me valuable suggestions and comments to improve my knowledge.

- Prof. Nguyen Tien Son and his family (Ngo Thi Tuyet and Nguyen Viet Ha) - I appreciate him and his family for helping and honestly advising me when I was working and living in Sweden. I really feel as the member of his family.

- Prof. Hiroshi Amano - thanks for growing excellent Mg-doped GaN which I used in my study.

- Prof. Bo Monemar - thanks for giving me valuable comments and suggestion to improve my paper.

- Dr. Takeshi Ohshima - thanks for helping me prepare samples in my thesis.

- Assoc. Prof. Olle Kordina - I want to thank you for your great support during my study. 
- Trinh Xuan Thang - my friend who lived together with me from the beginning. He always supported and helped me in work and life as well. I feel lucky to have a friend as him.

- Ian Booker - my friend who helped me much in setup and guided me to use some systems in the lab. I learnt a lot from him, and I wish him great success and luck in the future.

- Milan Yazdanfar - my friend, thanks for the funny stories and discussions, BBQ outside and for sharing his experience in life with me.

- $\mathbf{X u n ~ L i ~ - ~ m y ~ f r i e n d , ~ t h a n k s ~ f o r ~ d i s c u s s i o n s ~ a b o u t ~ m a n y ~ i n t e r e s t i n g ~}$ topics. I wish her having success and great luck in her life and work.

- Dinner Group (Pitsiri, Ted, Daniel, Zhafira, Martin, Chamseddine, Ted, Chao, Yuttapoom and others) - I really like our outside dinner activities. It is the time when I feel very happy to chat and cheer with my best friends.

- I also would like to thank all colleges in Semiconductor Materials Group. I feel very proud of being a member in the group. I believe that our group will develop even more in the future.

- I would like to say great thanks to my parents, my grandparents and my relatives who always believed in me and in my decisions, who never leave me when I face difficulties in my life.

- Finally, I want to thank my great love Nguyet and my dear daughter Khue (BonBon) who are the very very important people of my life. Without you, my life is nothing so thanks again for being together with me to get over the difficulties and share happiness in my life. 


\section{CONTENTS}

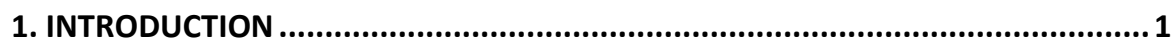

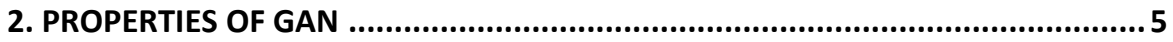

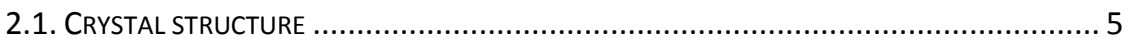

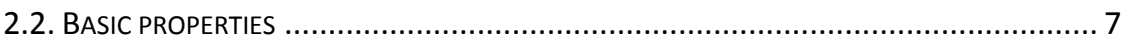

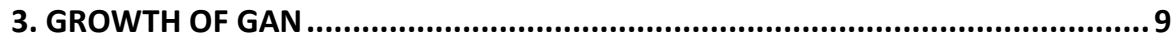

3.1. METALORGANIC CHEMICAL VAPOR DEPOSITION (MOCVD) .................................... 9

3.2. HALIDE (HYDRIDE) VAPOR PHASE EPITAXY (HVPE) ....................................... 11

4. CAPACITANCE TRANSIENT SPECTROSCOPY ............................................... 13

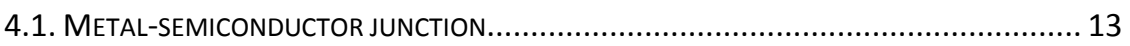

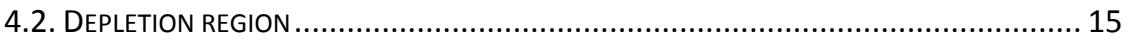

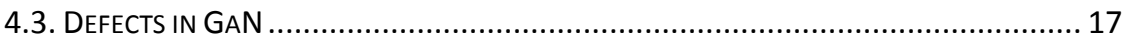

4.4. EMISSION AND CAPTURE OF CHARGE CARRIERS .................................................. 20

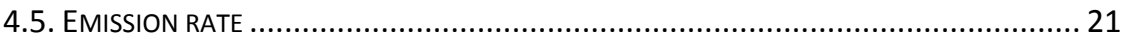

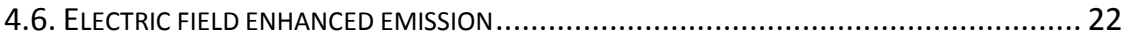

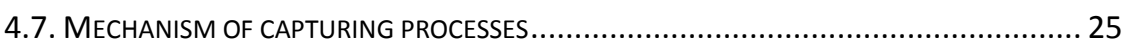

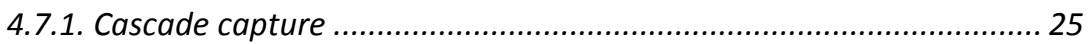

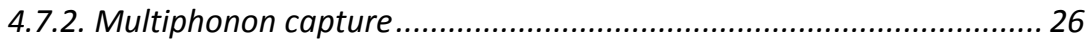

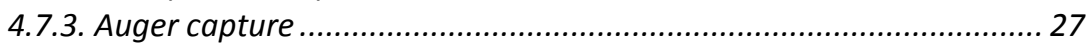

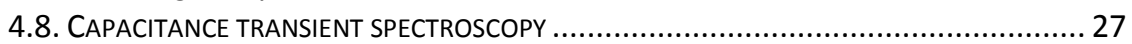

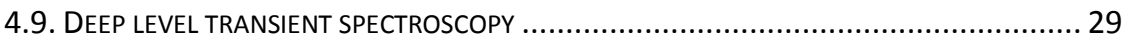

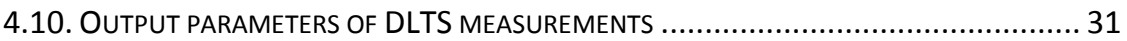

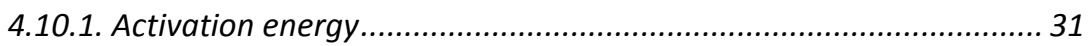

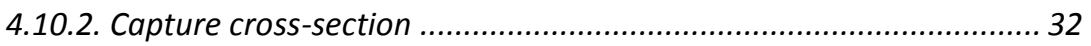

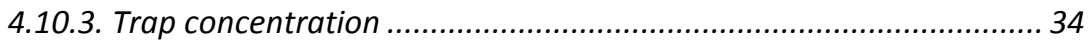

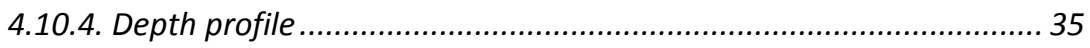

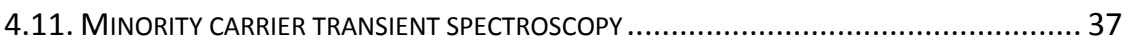

5. OTHER ELECTRICAL CHARACTERIZATION TECHNIQUES ................................ 40

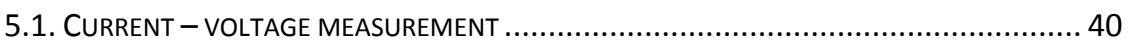

5.2. CAPACITANCE - VOLTAGE MEASUREMENT .................................................. 41

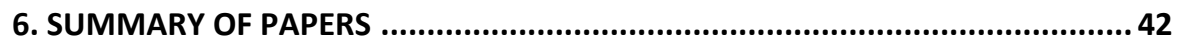

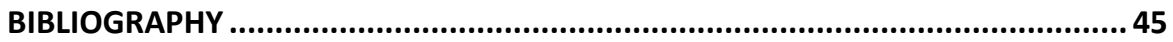




\section{INTRODUCTION}

In 1969, the first single crystal GaN was grown on sapphire substrate by Maruska and Tietjen [1] who used hydride vapor phase epitaxy (HVPE) technique. In the early time, the main hindrance was to grow high-quality crystals and to control the p-type doping in $\mathrm{GaN}$. After more than 20 years of study, several breakthroughs have been achieved such as the ability to grow high quality epitaxial and bulk $\mathrm{GaN}$ and to control conductivity of p-type GaN. These achievements have opened up new exciting applications of GaN.

$\mathrm{GaN}$ is a semiconductor consisting of the III group element $(\mathrm{Ga})$ and the $\mathrm{V}$ group element $(\mathrm{N})$. GaN has a direct and wide bandgap of $3.4 \mathrm{eV}$ at room temperature. Moreover, the bandgap can be controlled by making alloys with other elements such as aluminum (Al) for larger bandgap or indium (In) for smaller bandgap. This property makes GaN as a promising material for optoelectronics devices working in short wavelength range [2]-[5] such as blue and ultraviolet (UV) light emitting diodes [4], laser diode [3], green light emitting devices [6] and UV photodetector [7]-[10]. Additionally, GaN is also applied in the renewable energy field, particularly, making solar cells [11]-[13]. With other interesting properties such as high breakdown field, high electron mobility and high thermal conductivity, see Table 1.1, GaN is now widely applied for high-frequency and high-power devices such as transistors [7], [14]-[17], high electron mobility transistors (HEMT) [16], [18] and ultrahigh power switches [7], [19].

Nowadays, there are many methods of growing GaN, like metalorganic chemical vapor deposition (MOCVD) [20], molecular beam epitaxy (MBE) [21], hydride vapor phase epitaxy [22]-[24], high pressure solution growth (HPS) [25], [26], sodium (Na) flux [27], [28], and ammonothermal method [29]. The following techniques such as HPS, Na flux, ammonothermal method are used for growing thick bulk GaN while MOCVD and MBE are often used in fabricating thin layers of $\mathrm{GaN}$. The technique which has the largest growth rate is HVPE. The high growth rate and good control of impurities make HVPE being a primary and promising choice in producing $\mathrm{GaN}$ substrates commercially. Table 1.2 summarizes some main features of 
several techniques, which have been commonly used to grow bulk GaN.

Table 1.1. Basic parameters for some common semiconductors. The values are taken from references [17], [30]-[37].

\begin{tabular}{|c|c|c|c|c|c|c|c|}
\hline Semiconductor & $\mathrm{Si}$ & GaAs & $\mathrm{SiC}$ & GaN & AlN & InN & Diamond \\
\hline Bandgap $(\mathrm{eV})$ & 1.1 & 1.4 & 3.25 & 3.4 & 6.2 & 0.64 & $5.46-5.6$ \\
\hline $\begin{array}{l}\text { Electron Mobility at } \\
300 \mathrm{~K}\left(\mathrm{~cm}^{2} / \mathrm{Vs}\right)\end{array}$ & 1500 & 8500 & 700 & $\begin{array}{l}1000- \\
2000\end{array}$ & 300 & 3200 & $\leq 2200$ \\
\hline Saturated Electron & & & & & & & \\
\hline $\begin{array}{l}\text { Velocity } \\
\mathrm{cm} / \mathrm{s})\end{array} \quad\left(\times \quad 10^{7}\right.$ & 1 & 1.3 & 2 & 2.5 & & & \\
\hline $\begin{array}{l}\text { Breakdown } \\
(\mathrm{MV} / \mathrm{cm})\end{array}$ & 0.3 & 0.4 & 3 & 3.3 & $\begin{array}{l}1.2- \\
1.8\end{array}$ & 2 & $1-10$ \\
\hline Dielectric constant & 11.8 & 12.8 & 10 & $\begin{array}{l}8.9- \\
9.0\end{array}$ & 8.7 & 15.3 & 5.5 \\
\hline $\begin{array}{l}\text { Thermal } \\
\text { Conductivity } \\
\text { (W/cmK) }\end{array}$ & 1.5 & 0.5 & 4.5 & $>1.5$ & $<2.85$ & 0.45 & $6-20$ \\
\hline
\end{tabular}

Table 1.2. Features of some common growth techniques for growing bulk GaN

\begin{tabular}{|c|c|c|c|c|}
\hline $\begin{array}{l}\text { Growth } \\
\text { Method }\end{array}$ & $\begin{array}{l}\text { High pressure } \\
\text { solution } \\
\text { (HPS)[26][25] }\end{array}$ & $\begin{array}{l}\text { Ammonothermal } \\
\text { growth }\end{array}$ & $\begin{array}{c}\text { Na-flux } \\
{[27],} \\
{[28],[38]}\end{array}$ & HVPE \\
\hline Conditions & $\begin{array}{l}\leq 2 \mathrm{GPa} \\
\leq 1700^{\circ} \mathrm{C}\end{array}$ & $\begin{array}{l}400 \mathrm{MPa} \\
600^{\circ} \mathrm{C}\end{array}$ & $\begin{array}{l}5-9.5 \mathrm{MPa} \\
600- \\
900^{\circ} \mathrm{C}\end{array}$ & $\begin{array}{l}1 \mathrm{~atm} \\
1000- \\
1100^{\circ} \mathrm{C}\end{array}$ \\
\hline Growth rate & $\begin{array}{l}0.1 \mu \mathrm{m} / \mathrm{h} \text { in c- } \\
\text { axis } \\
0.1 \mathrm{~mm} / \mathrm{h}-\perp \mathrm{c}- \\
\text { axis }\end{array}$ & $\begin{array}{l}0.1 \mathrm{~mm} / \text { day } \\
\text { in }<0001>[29]\end{array}$ & & $\begin{array}{l}100-500 \\
\mu \mathrm{m} / \mathrm{h} \text { in } \\
\langle 0001\rangle\end{array}$ \\
\hline Quality & High & High & High & Normal \\
\hline Thickness & $0.1 \mathrm{~mm}$ & cm-scale & $<10 \mathrm{~mm}$ & mm-scale \\
\hline $\begin{array}{l}\text { Mass } \\
\text { production }\end{array}$ & $\mathrm{Bad}$ & Good & Good & Good \\
\hline Cost & Expensive & Expensive & Expensive & Cheap \\
\hline
\end{tabular}

Since there is a lack of native substrates of $\mathrm{GaN}$, foreign substrates such as sapphire or $\mathrm{SiC}$ are commonly used. The dislocation density in $\mathrm{GaN}$ grown on foreign substrates, which is due to the lattice mismatch, is quite high in $1 \mu \mathrm{m}$ thick layer (in the order of $>10^{9} \mathrm{~cm}^{-2}$ ). However, the dislocation density is dropping with thickness, and for a layer of $1 \mathrm{~mm}$, the dislocation density is $\sim 10^{6} \mathrm{~cm}^{-2}$, which is necessary for fabrication of $\mathrm{GaN}$ based lasers. The lowest dislocation density 
now, which can be achieved by the ammonothermal method, is $\sim 10^{4}$ $\mathrm{cm}^{-2}$. However, the drawbacks of this method are the low growth rate and the high pressure and high temperature of growth condition, leading to high cost of the GaN substrates. Additional problem related to the high temperature is the high impurity concentration by using corrosive agents. In order to deal with this problem, the promising solution has been suggested by the company AMMONO, in which ammonothermal grown GaN substrates can be used as seeds for HVPE growth [40]. Using this approach, crystalline material of high quality and low threading dislocation $\left(5 \times 10^{4} \mathrm{~cm}^{-2}\right)$ was produced.

Defects are important since they influence the electronic properties of $\mathrm{GaN}$ and depending on the origin, we can classify them as intrinsic defects or impurities. An impurity is one or several foreign atoms in the host crystal while an intrinsic defect is an imperfection in the host's crystal lattice. $\mathrm{GaN}$ is normally unintentionally doped by oxygen and silicon impurities which makes it n-type. It is difficult to obtain p-type $\mathrm{GaN}$ with a high hole concentration. The first p-type $\mathrm{GaN}$ with a hole concentration of $\sim 2 \times 10^{16} \mathrm{~cm}^{-3}$ was fabricated in 1989 by Amano et al. [39] in which magnesium $(\mathrm{Mg})$ was used as the dopant. Formation of the complex with $\mathrm{H}$ during cooling after growth leads to a low hole concentration if the material is not annealed in a hydrogen-free atmosphere. One can use $\mathrm{Zn}$ and $\mathrm{Cd}$ as p-type dopant; however, these two elements are inefficient due to the high activation energies [40], [41] ( $\mathrm{Zn} \mathrm{0.34} \mathrm{eV,} \mathrm{Cd} \mathrm{0.55} \mathrm{eV).} \mathrm{That} \mathrm{is} \mathrm{why,} \mathrm{Mg}$ with its rather high thermal activation energy of $0.17 \mathrm{eV}$ [42] is the best choice for making p-type $\mathrm{GaN}$ even though just a few percent of the $\mathrm{Mg}$ atoms is activated at room temperature.

The presence of defects can give rise to energy levels in the bandgap that may trap electrons or holes. Depending on how localized the trapped carriers are to the defect, we classify them as deep or shallow levels. Shallow levels have a long ranged potential, where a trapped carrier is relatively loosely bounded to the defect while deep levels have a short ranged potential where a trapped carrier is tightly bound. In principle, these levels can affect GaN-based devices in the both negative and positive ways. Therefore, it is necessary to understand the properties and to identify them. When we know their properties, one can predict how they will influence the behavior of 
devices, and thereby, optimize the performance of the device for its application. Normally, defects can be introduced either intentionally or unintentionally into semiconductors during the growth process, during processing of the device or from the working environment. Especially for GaN, due to the lack of native substrates, most of the $\mathrm{GaN}$-based devices are fabricated on a foreign substrate such as silicon carbide $(\mathrm{SiC})$ or sapphire $\left(\mathrm{Al}_{2} \mathrm{O}_{3}\right)$. Growth on foreign substrates gives rise to high threading dislocation densities, and they can give rise to deep levels that influence the performance of the device. There are a lot of studies on defects in GaN grown by other techniques such as MOCVD[43]-[45], MBE[46], [47] and HVPE [48]-[50].

In order to study defects and to understand their origin, it is convenient to intentionally introduce them by irradiation technique, in which an electron or ion beam (He, $\mathrm{H}$ ion) [51]-[65] is used. By varying the beam energy and fluence, we can judge the nature of them. The most powerful and commonly used technique for studying electronic properties of deep levels in semiconductors is deep level transient spectroscopy (DLTS) which was invented by D.V. Lang in 1974. This technique is based on measuring capacitance transients caused by the thermal emission process of charge carriers from deep levels. The advantage of this technique is that it is simple to obtain important information of defects such as activation energy, capturecross section, defect concentration and depth profile of defects. In DLTS technique using Schottky diodes, one normally observes deep levels related to trapping of majority charge carriers. To characterize minority carrier traps, another method, named minority charge carrier transient spectroscopy (MCTS) is commonly used. Other important measurement techniques for electrical characterization of defects are current-voltage measurement (IV), capacitance-voltage measurement (CV) and Hall measurement. 


\section{PROPERTIES OF GaN}

\subsection{Crystal structure}

GaN has two common polytypes: the zinc-blende (ZB) and wurtzite (WZ), see Fig. 2(a) and (b), respectively. In ZB phase, GaN has space group $\mathrm{F} \overline{4} 3 \mathrm{~m}$ and each cubic unit cell consists of four $\mathrm{Ga}$ atoms and four $\mathrm{N}$ atoms. The unit cell contains two tetrahedrons in which $\mathrm{N}$ atom is surrounded by four $\mathrm{Ga}$ atoms and vice versa. The lattice constant of zinc-blende structure GaN thin films grown on (001) $\mathrm{Si}$ is about 4.49 $\AA$ A66]. However, the ZB phase is not stable as the WZ phase that has a hexagonal unit cell. The ZB phase is only obtained when growing epitaxy thin films on (001) substrate. This leads to a high threading dislocation density and worsens the quality of film. In the thesis, we have studied bulk $\mathrm{GaN}$ with the stable WZ phase.

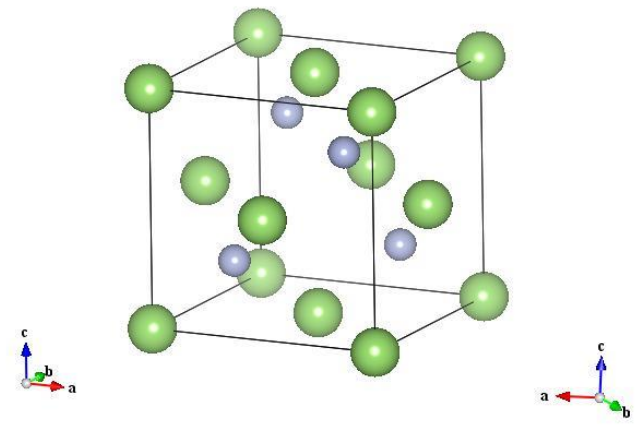

(a)

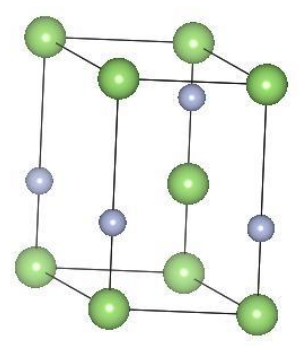

(b)

Figure 2.1. (a) zinc-blende structure and (b) wurtzite structure of GaN where Ga is illustrated as large green atom and $\mathrm{N}$ as small gray atom.

The space group for WZ is $\mathrm{P} 63 \mathrm{mc}$ in which the basic is comprised of two $\mathrm{Ga}$ atoms at $(0,0,0)$ and $\left(\frac{1}{3}, \frac{2}{3}, \frac{1}{2}\right)$ and two $\mathrm{N}$ atoms at $\left(0,0, \frac{3}{8}\right)$ and $\left(\frac{1}{3}, \frac{2}{3}, \frac{1}{2}+\frac{3}{8}\right)$. The WZ structure is considered as the interpenetration of two hexagonal closed packed lattices of $\mathrm{Ga}$ and $\mathrm{N}$ (Fig. 2.2) where the distance between $\mathrm{Ga}$ and $\mathrm{N}$ along the direction [0001] is $\frac{3}{8} c$ in ideal case. Here, $c$ is the height of a hexagonal unit cell. The lattice constants at $300 \mathrm{~K}$ are $a=3.189 \AA$ and $c=5.185 \AA$ and these constants depend on the temperature and the doping 
concentration. Depending on which kind of structure, GaN has different properties, shown in Table 2.1. GaN has also one more polytype with rocksalt structure. However, the structure is not stable and the only condition to get this structure is under very high pressure and therefore, it has never been studied in detail.

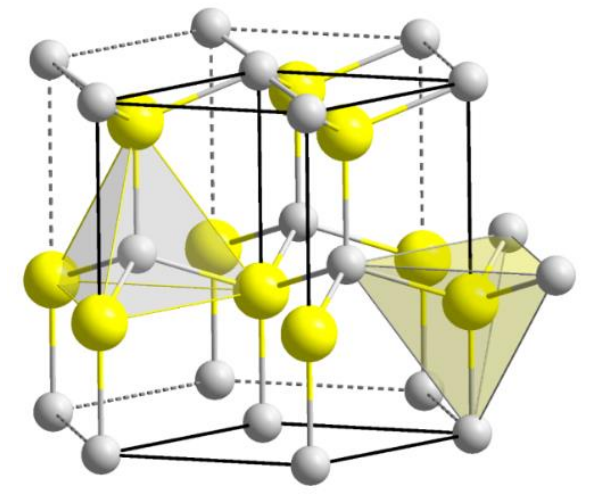

Figure 2.2. Wurtzite structure of $\mathrm{GaN}$ shown as two interpenetrating lattice of $\mathrm{Ga}$ (yellow sphere) and $\mathrm{N}$ (grey sphere).

Table 2.1. Basic properties of $\mathrm{WZ} \mathrm{GaN}$ and $\mathrm{ZB} \mathrm{GaN[67][36]}$

\begin{tabular}{|c|c|c|}
\hline Parameters & "Wurtzite GaN & "Zinc-blende GaN \\
\hline Lattice constant $[\AA]$ & $\mathrm{a}=3.189, \mathrm{c}=5.185$ & 4.5 \\
\hline The stacking order & $\begin{array}{c}\mathrm{AaBb} \text { along }[0001] \\
\text { direction }\end{array}$ & $\begin{array}{l}\text { AaBbCc along [111] } \\
\text { direction }\end{array}$ \\
\hline$P_{S P}\left(C / m^{2}\right)$ & -0.034 & \\
\hline $\begin{array}{l}\text { Effective density of states } \\
\text { in the conduction band } N_{C} \\
\left(\mathrm{~cm}^{-3}\right)\end{array}$ & $N_{C}=4.3 \times 10^{14} \times T^{\frac{3}{2}}$ & $N_{C}=2.3 \times 10^{14} \times T^{\frac{3}{2}}$ \\
\hline $\begin{array}{l}\text { Effective density of states } \\
\text { in the valence band } N_{V} \\
\left(\mathrm{~cm}^{-3}\right)\end{array}$ & $\begin{array}{l}N_{V} \\
=8.9 \times 10^{15} \times T^{\frac{3}{2}}\end{array}$ & $N_{V}=8.0 \times 10^{15} \times T^{\frac{3}{2}}$ \\
\hline $\begin{array}{l}\text { Effective electron mass } \\
\mathrm{m}_{\mathrm{e}}\end{array}$ & $0.20 \mathrm{~m}_{0}$ & $0.13 \mathrm{~m}_{0}$ \\
\hline $\begin{array}{l}\text { Effective mass of density } \\
\text { of state } m_{v}\end{array}$ & $1.5 \mathrm{~m}_{0}$ & $1.4 \mathrm{~m}_{0}$ \\
\hline $\begin{array}{l}\text { Breakdown field at RT } \\
\left(\mathrm{Vcm}^{-1}\right)\end{array}$ & $5 \times 10^{6}$ & $3.3 \div 5 \times 10^{6}$ \\
\hline Dielectric constant & 8.9 (static) & 9.7 (static) \\
\hline $\begin{array}{l}\text { Optical phonon energy } \\
(\mathrm{meV})\end{array}$ & $\begin{array}{c}5.35 \text { (high frequency) } \\
91.2\end{array}$ & $\begin{array}{c}5.3 \text { (high frequency) } \\
87.3\end{array}$ \\
\hline
\end{tabular}




\subsection{Basic properties}

The most interesting property of $\mathrm{GaN}$ that makes it promising for optoelectronics applications, especially, blue and UV LEDs is the large direct bandgap of $3.4 \mathrm{eV}$. In Fig. 2.3, we observe that the bandgap of $\mathrm{GaN}$ correspond to a wavelength about $360 \mathrm{~nm}$ (UV). Another advantage of $\mathrm{GaN}$ is the possibility to control the bandgap by making alloy with $\mathrm{Al}$ or In in order to increase or reduce the bandgap, respectively. The group of materials with $\mathrm{GaN}$ and its alloys with $\mathrm{Al}$ and In refers as the III-nitrides. Thus, by using the III-nitrides, it is possible to fabricate LEDs from green to the UV region. In LEDs, the light comes from the recombination of electrons locating around the minimum of the conduction band and holes locating around the maximum of the valence band, see Fig. 2.4. In case of a direct bandgap, the recombination process requires two particles: electron in the conduction band and hole in the valence band. This process in case of the indirect band requires three particles: electron, hole and phonon. This makes the probability for an electron-hole recombination significant lower and affects the efficiency of the light emitting process (Fig. 2.4). This is the reason why $\mathrm{SiC}$, which has an indirect bandgap, is less suitable as a light emitter despite that the bandgap is similar to GaN.

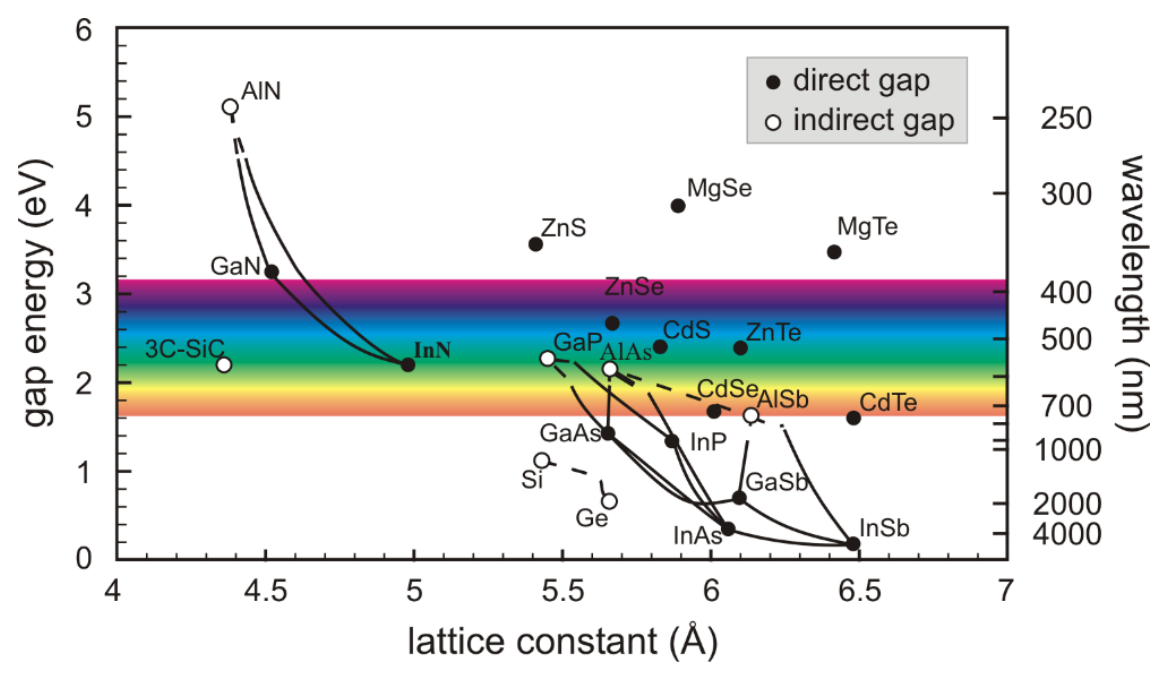

Figure 2.3. Bandgaps and lattice constant of some common semiconductor materials 


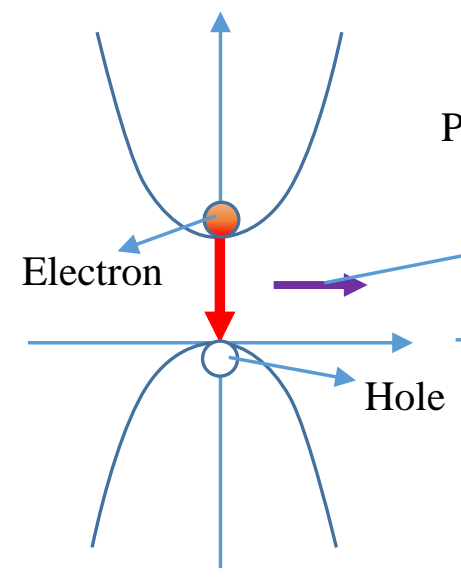

(a)

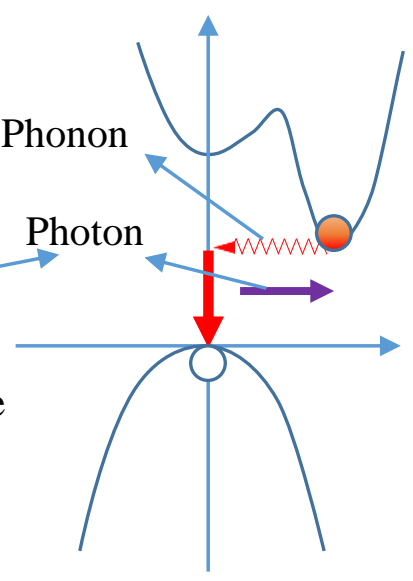

(b)

Figure 2.4. The diagram of (a) direct bandgap and (b) indirect bandgap in kspace

Other outstanding properties of $\mathrm{GaN}$ are a relatively high thermal conductivity, a high electron mobility and a high-breakdown field, which make it possible to fabricate high-power and high-frequency devices like photodetectors, transistors and switches [7], [9], [10], [14]-[19]. GaN is also known as a compound having a high chemical stability, however, the chemical stability poses technological challenges for device processing. There have been many studies on etching of $\mathrm{GaN}$ with different etchants such as acids, bases, alkali solutions [68]-[73] at different temperatures and most of them showed an exceptional chemical stability of $\mathrm{GaN}$. In early studies by Chu et al. [71], GaN was found to be dissolve in sodium hydroxide $(\mathrm{NaOH})$. The main problem with this etchant is the formation of gallium hydroxide $(\mathrm{GaOH})$ which is insoluble. Later, Pankove et al. tried to address this problem by electrolytic etching technique [68]. The quality of GaN significantly affects the ability of wet etching, i.e. the low quality has the high etching rate [74]. Another interesting behavior related to wet etching is the dependence of GaN polarity. In Palacios et al.'s report [75], using kali hydroxide $(\mathrm{KOH})$ at $80^{\circ} \mathrm{C}$, etching was only observed on the $\mathrm{N}$-face and not the Ga-face. Nowadays, phosphoric acid $\left(\mathrm{H}_{3} \mathrm{PO}_{4}\right)$ [76], [77] is the most commonly used etchant in $\mathrm{GaN}$ device fabrication. The $\mathrm{H}_{3} \mathrm{PO}_{4}$ etching process is often carried out at the high temperatures $\left(\sim 190^{\circ} \mathrm{C}\right)$ with the etching rate varying in the range of $0.013-3.2 \mu \mathrm{m} / \mathrm{min}[76]$. 


\section{GROWTH OF GaN}

\subsection{Metalorganic chemical vapor deposition (MOCVD)}

Nowadays, MOCVD is the most common method to grow device structures in the semiconductor industry. This technique is preferred for growing thin layers due to several outstanding abilities. For example, by using MOCVD one can easily control the epilayer thickness by changing some basic parameters such as temperature, pressure, flow rate of precursor, etc. Moreover, there exist a variety of pure precursors, which makes it possible to grow some different types of semiconductors or other types of material. In principle, the MOCVD growth process consists of several basic steps, which are mentioned below, see Fig. 3.1.

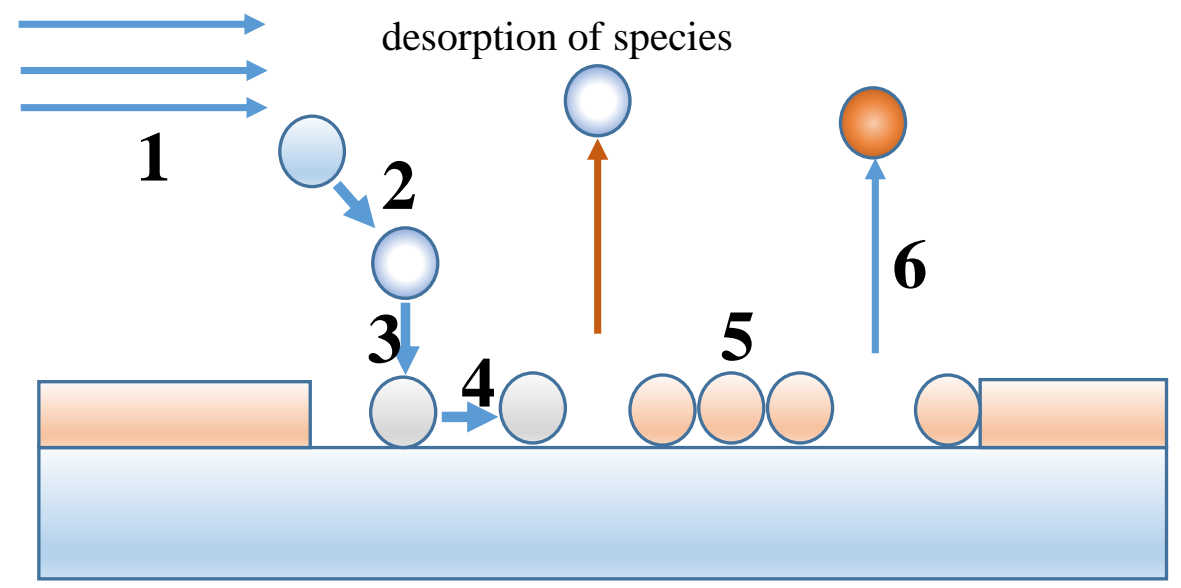

Figure 3.1. Precursor transport and reaction processes in conventional CVD

Precursors are transported with a carrier gas to the growth zone where precursor reacts with each other.

1. Precursors react in gas phase and create gaseous by-products and reactants

2. Reactants are transported to the substrate surface by a diffusion process.

3. On the substrate surface, the transported reactants are adsorbed

4. Surface diffusion of reactants to growth sites. 
5. Growth takes place on the surface by reactions.

6. The by-products from the reactions in step 5 are desorbed then evacuated away from the growth zone.

The quality of GaN depends strongly on the quality of precursors and the substrates. Due to low cost, sapphire has been widely used as a substrate even though the lattice mismatch is quite high. To deal with this problem, Amano and Akasaki [78] used AlN as a buffer layer. This method has been widely and commercially used in growth of $\mathrm{GaN}$ until now. The buffer layer of $\mathrm{GaN}$ or AlN plays a role as a nucleation layer that absorbs the strain appearing during the growth process. The buffer layer has a thickness of few tens of $\mathrm{nm}$ and is often fabricated at a low temperature.

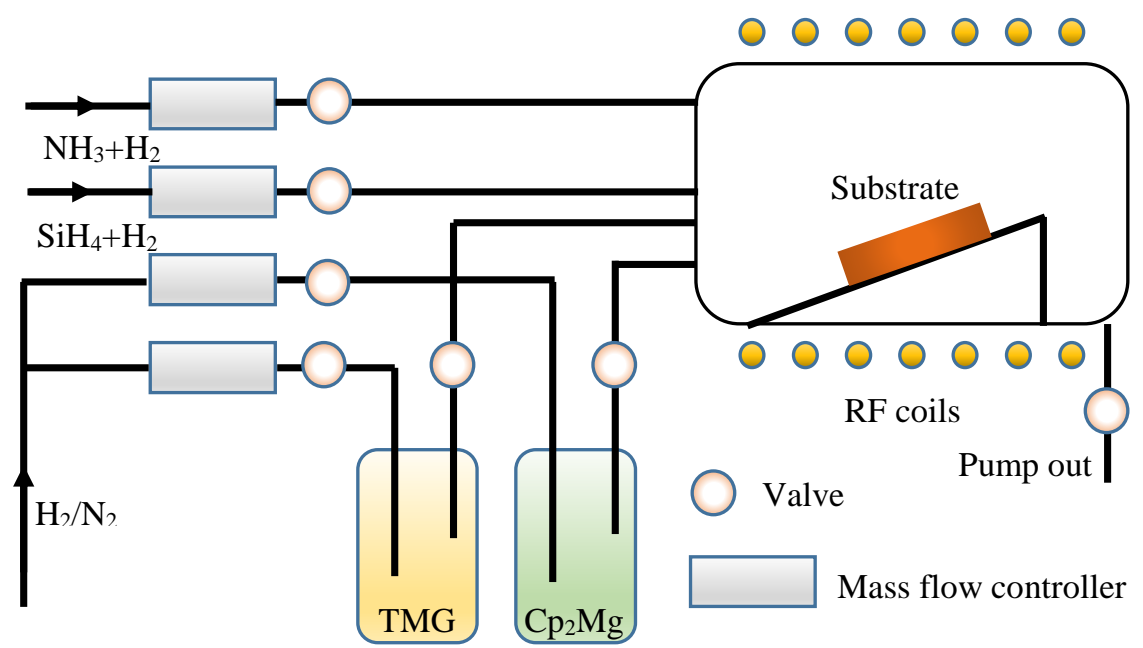

Figure 3.2. Schematic diagram of the MOCVD process which $\mathrm{SiH}_{4}$ and $\mathrm{Cp}_{2} \mathrm{Mg}$ are used for growth of n-type and p-type $\mathrm{GaN}$

Additionally, MOCVD enables the possibility to easily dope the material by adding organic compounds as a dopant source. In doping of $\mathrm{GaN}, \mathrm{Mg}$ is used to make the material p-type and $\mathrm{Si}$ is used for $\mathrm{n}$ type doping. In MOCVD system, bis-cyclopentadienylmagnesium $\left(\mathrm{Cp}_{2} \mathrm{Mg}\right)$ and silane $\left(\mathrm{SiH}_{4}\right)$ are commonly used as a source of $\mathrm{Mg}$ and $\mathrm{Si}$, respectively. These two compounds are transported to the substrate by a carrier gas of $\mathrm{H}_{2}, \mathrm{~N}_{2}$ or a mixture of $\mathrm{H}_{2} / \mathrm{N}_{2}$. Fig. 3.2 shows a schematic drawing of a MOCVD system with the possibility of doping. 


\subsection{Halide (Hydride) vapor phase epitaxy (HVPE)}

HVPE has been used for growth of GaN for 45 years. The first successful growth of single crystal GaN was done by Maruska in 1969 [1]. The characteristic of this technique is a high growth rate (100-500 $\mu \mathrm{m} /$ hour along <0001> direction) [79], which makes it as the preferred choice for growing thick GaN bulk material. However, the main limitation is the problem of dislocations generation due to a lattice mismatch $\left(>10^{6} \mathrm{~cm}^{-2}\right)$ with the foreign substrate. In order to reduce the threading dislocation density, a technique named epitaxial lateral overgrowth (ELOG) can be used, more details in Ref. [80], [81].

Many studies showed that high quality GaN can be obtained by using HVPE in combination with other techniques. By using MOCVD grown $\mathrm{GaN}$ as starting layer, the initial growth is facilitated. By using ammonothermal growth substrate, the crystal quality is very high from the beginning of growth. The quality of GaN crystal can be also improved by growing a low-temperature GaN buffer layer which is expected to reduce the propagation of threading dislocations from the $\mathrm{GaN}$ and the substrate interface [22].

Most samples in this thesis are thick free-standing GaN grown in a vertical hot wall HVPE reactor described in Fig. 3.3. The chamber is made of quartz and divided into two zones (source zone and growth zone). In Linköping University's vertical HVPE reactor, the source zone is heated by a resistive heater at the lower part of the reactor. In the source zone, gallium chloride is formed by flowing $\mathrm{HCl}$ through a boat containing liquid $\mathrm{Ga}$. The temperature of the source zone is kept at $\sim 800-900{ }^{\circ} \mathrm{C}$ at which the dominant chemical reaction between $\mathrm{Ga}$ and $\mathrm{HCl}$ occurs as following [81], [82]:

$$
G a(l)+H C l(g)=\operatorname{GaCl}(g)+\frac{1}{2} H_{2}(g)
$$

When gaseous gallium chloride is formed, gallium chloride is transported to the growth zone through the quartz tube by a carrier gas of $\mathrm{H}_{2}$ or $\mathrm{H}_{2} / \mathrm{N}_{2}$. In the growth zone, a mixture of ammonia and $\mathrm{H}_{2}$ is transported into the reaction region where ammonia reacts with gallium chloride to form $\mathrm{GaN}$ according to the reaction: 


$$
\operatorname{GaCl}(g)+\mathrm{NH}_{3}(g)=\mathrm{GaN}+\mathrm{HCl}+\mathrm{H}_{2}
$$

One issue that needs to be considered for growing thick $\mathrm{GaN}$ is the parasitic growth, which occurs at the precursors gas inlets and at the outlet (ammonia easily reacts with gallium chloride to form $\mathrm{GaN}$, which deposits on the inlet tubes and reactor walls). If the GaN growth run is long (which is necessary to grow bulk GaN), the parasitic growth will prevent precursors to enter the reactor. To address this problem, a flow of light gas $\left(\mathrm{H}_{2}\right.$ or $\left.\mathrm{H}_{2} / \mathrm{N}_{2}\right)$ is introduced between the ammonia tube and the gallium chloride, depicted in Fig. 3.3. This flow will prevent the ammonia gas from mixing with the gallium chloride before they arrive to the substrate.

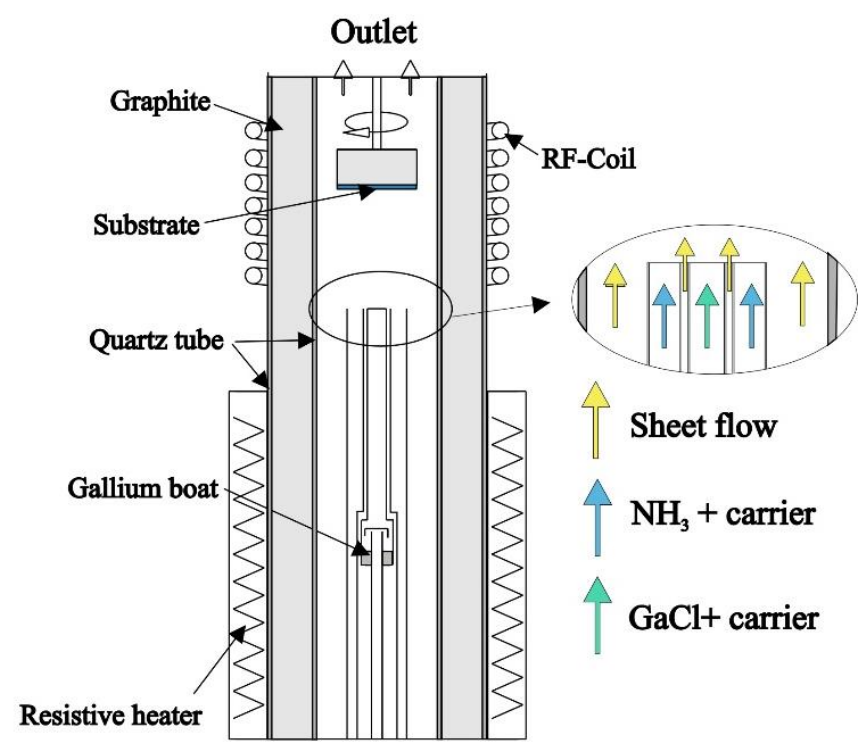

Figure 3.3. Schematic diagram of a vertical HVPE reactor for growth of GaN [81] 


\section{CAPACITANCE TRANSIENT SPECTROSCOPY}

\subsection{Metal-semiconductor junction}

Basically, the metal-semiconductor (MS) junction can behave as a rectifying Schottky junction that only conducts current in one direction or a linear Ohmic junction that the current is linearly dependent on the applied voltage. For studying deep levels, a p-n diode can be used; however, a Schottky diode is in many times preferred due to simple fabrication. A Schottky diode is fabricated by forming both a Schottky and an Ohmic junction. In the thesis, all samples used for electrical characterization are prepared as Schottky diodes which consist of two types of MS junction. Since we are only using n-type GaN, we will restrict the discussion to n-type Schottky diodes. Hence, this part will focus on the characteristics of the n-type Schottky diode fabricated by making a contact between metal and n-type GaN semiconductor. When the diode is reversely biased, the applied voltage $V a$ is negative and when the voltage $V a$ is positive, the diode is forwardly biased.

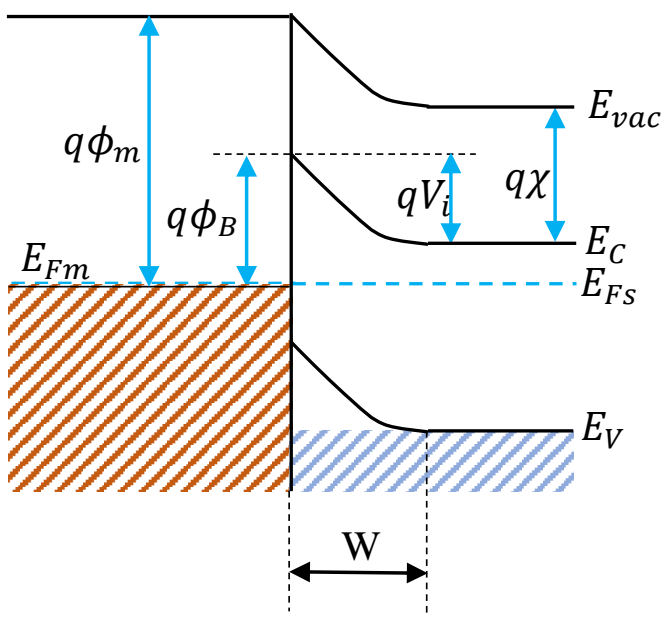

(a)

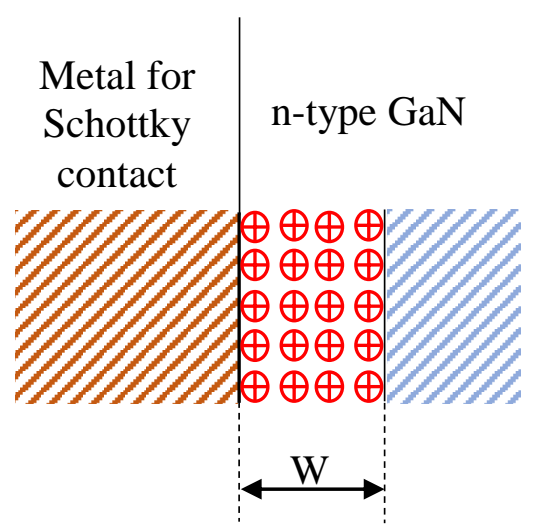

(b)

Figure 4.1. Energy band diagram (a) and the positive space charge region (b) for an n-type Schottky diode

To understand the principle of forming a barrier between a semiconductor and a metal, it is convenient to use an energy band diagram. Fig. 4.1(a) shows a band diagrams of a metal and an n-type 
semiconductor at thermal equilibrium condition forming the Schottky diode. $E_{F m}$ and $E_{F s}$ are the Fermi level of the metal and semiconductor, respectively. $\phi_{m}$ is the work function of the metal which is the potential between the Fermi level and the vacuum level $\left(E_{v a c}\right) \cdot \chi$ is the electron affinity (EA) defining the energy needed to remove an electron in the conduction band edge $\left(E_{C}\right)$ to the vacuum level. Depending on the relation between $\phi_{m}$ and $\chi$, the M-S junction can behave as the Schottky or Ohmic junction. For GaN, the EA is determined by theoretical calculation to about $1.44 \mathrm{eV}$ [83] and 1.88 $\mathrm{eV}$ [84]. However, these values are much lower than the experimental value which is about $4.1 \mathrm{eV}$ at room temperature [36].

When a metal, having a higher work function, contacts with a semiconductor, higher-energy electrons in the semiconductor will diffuse through the junction to the metal and create a diffusion current. This leaves positive ionized donors in the semiconductor which give rise to an electric field, as shown in Fig. 4.1(b). This field will create a drift current. The diffusion of electrons continues until the electric field is high enough to prevent electrons in the semiconductor from further diffusion. Thus, the diffusion current is equal to the drift current and the Fermi levels in the metal, and the semiconductor are equal in thermal equilibrium. At this time, a barrier for the carrier $\phi_{B}$ is formed to hinder further electron diffusion between the two regions, as depicted in Fig. 4.1(a). The barrier height which is the difference between the metal work function and the affinity of the semiconductor:

$$
\phi_{B}=\phi_{m}-\chi
$$

The barrier height is the potential between the Fermi level of the metal and the conduction band edge. Therefore, the value of the barrier height, for a certain semiconductor such as $\mathrm{GaN}$, is dependent on the metal. The barrier height of some metals which is commonly used for making Schottky diode on n-type GaN is shown in Table 4.1. To form the Schottky contact on n-type GaN, there are two requirements that need to be fulfilled:

- The doping concentration is not too high

- The work function of the metal has to be larger than the ntype semiconductor. 
Table 4.1. Summary some important parameters of metal commonly used for making contact with n-type GaN[85]-[87]

\begin{tabular}{|c|c|c|c|c|c|c|c|}
\hline Metal & $\mathrm{Au}$ & $\mathrm{Ni}$ & $\mathrm{Pt}$ & $\mathrm{Ti}$ & $\mathrm{Al}$ & In & $\mathrm{Ag}$ \\
\hline $\begin{array}{l}\text { Work } \\
\text { function }\end{array}$ & 5.1 & 5.15 & 5.65 & 4.33 & 4.08 & 4.09 & 4.26 \\
\hline $\begin{array}{l}\text { Barrier } \\
\text { height }\end{array}$ & $\begin{array}{c}0.87- \\
0.98\end{array}$ & $\begin{array}{c}0.95- \\
1.13\end{array}$ & $\begin{array}{l}1.01- \\
1.16\end{array}$ & - & - & - & - \\
\hline Contact & Schottky & Schottky & Schottky & Ohmic & Ohmic & Ohmic & Ohmic \\
\hline
\end{tabular}

The term $V_{i}$ in Fig. 4.1(a) is called the built-in potential which is the energy needed to be supplied to an electron in the semiconductor to surmount the potential barrier. The built-in potential for a metalsemiconductor junction in this case can be obtained by the equation below [88]:

$$
V_{i}=\phi_{M}-\chi-\frac{E_{C}-E_{f s}}{q}=\phi_{B}-\frac{k T}{q} \ln \frac{N_{C}}{N_{d}}
$$

where $k$ is the Boltzmann constant, $q$ the charge of the carrier, $T$ the temperature, $N_{d}$ the donor concentration and $N_{C}$ is the effective density of states in the conduction band which is calculated by [89]:

$$
N_{C}=2\left[\frac{2 \pi m_{e}^{*} k T}{h^{2}}\right]^{3 / 2}
$$

where $h$ is Plank constant and $m_{e}$ is the effective electron mass. For nGaN Schottky, it is convenient to use the approximate equation [90]:

$$
V_{i}=\frac{1}{3}\left(3.503+\frac{5.08 \times 10^{-4} T^{2}}{T-996}\right)(\mathrm{eV})
$$

\subsection{Depletion region}

As can be seen in Fig. 4.1, in thermal equilibrium, there is a region, named the depletion or space charge region, formed in the semiconductor in which there is no free carrier. In principle, the depletion region extends into the metal region; however, the extension 
into the metal is negligible due to the much larger electron concentration than the doping concentration in the semiconductor [91]. The depletion width $W$ can be calculated by using Poisson's equation and for the case of a Schottky contact it is given by:

$$
W=\sqrt{\frac{2 \varepsilon_{r} \varepsilon_{0} V_{i}}{q N_{d}}}=\sqrt{\frac{2 \varepsilon V_{i}}{q N_{d}}}
$$

where $\varepsilon, \varepsilon_{r}$ and $\varepsilon_{0}$ are the permittivity, the relative permittivity (also called electric constant, $\left.\varepsilon_{r}(G a N)=8.9\right)$, and the vacuum permittivity $\left(\varepsilon_{0}=8.86 \times 10^{-12} \mathrm{~F} / \mathrm{m}\right)$, respectively; $q=1.6 \times 10^{-19} \mathrm{C}$ is the elementary charge; $N_{d}$ is the donor concentration and $V_{i}$ is the built-in potential.

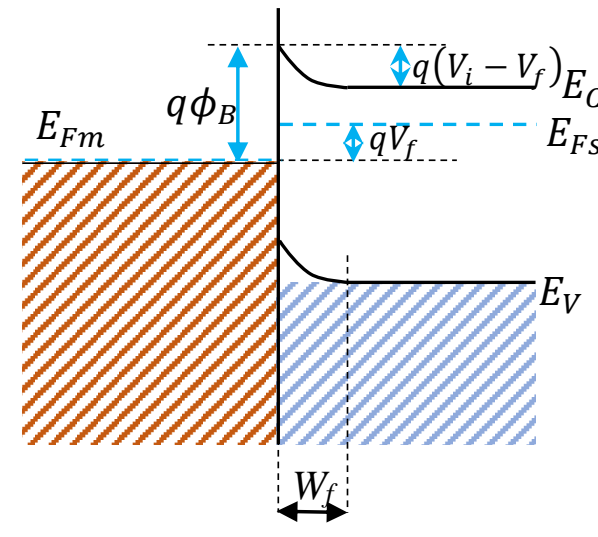

(a)

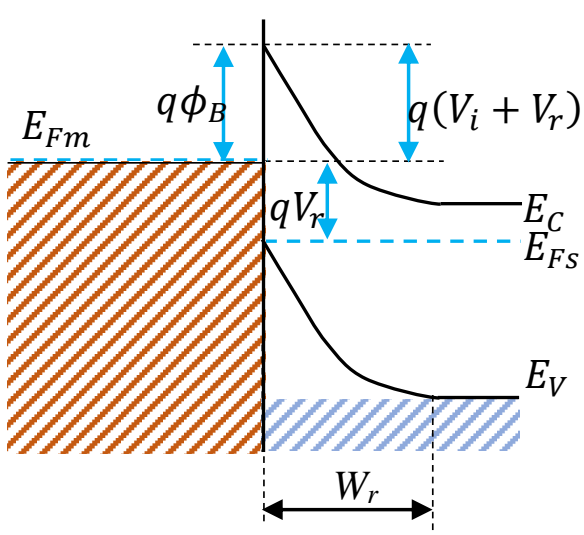

(b)

Figure 4.2. Band diagram of n-type Schottky contact under a forward bias (a) and a reverse bias (b)

The depletion region depends strongly on the applied voltage. The depletion width widens when a reverse bias applies to the Schottky diode and shortens in case of reduction of the bias. Fig. 4.2 shows the change of the depletion region when applying a forward bias and a reverse bias. The depletion width in the cases of a forward bias and a reverse bias is calculated by the equation (4.6) and (4.7), respectively.

$$
W_{f}=\sqrt{\frac{2 \varepsilon_{r} \varepsilon_{0}\left(V_{i}-V_{f}\right)}{q N_{d}}}
$$




$$
W_{r}=\sqrt{\frac{2 \varepsilon_{r} \varepsilon_{0}\left(V_{i}+V_{r}\right)}{q N_{d}}}
$$

Depletion width is a very important parameter when doing electrical characterization like capacitance-voltage measurement (CV), deep level transient spectroscopy (DLTS) which will be mentioned in later. The depletion width $W$ can be determined by measuring the capacitance and by using Eq. 4.8 [91] in which the depletion region is considered as the capacitance of two parallel plates with area A. By studying the capacitance as a function of applied voltage, one can obtain important parameters such as the depth profile of doping concentration.

$$
C=\frac{\varepsilon_{r} \varepsilon_{0} A}{W}
$$

\subsection{Defects in GaN}

In all crystals, defects always exist and can affect the material in the both positive and negative ways. Some of them are introduced intentionally to change the properties of the material such as the thermal conductivity, the hardness or the conductivity. Others may be introduced unintentionally during growth, by the ambient or during processing of the material which is often detrimental to the performance of a device such as heating, reducing the efficiency and lifetime. Fig. 4.3 presents some common defects, including point defects and line defects in a semiconductor crystal: (1) vacancy, (2) self-interstitial, (3) foreign interstitial, (4) foreign substitutional, (5) stacking fault, (6) dislocation, (7) vacancy type dislocation loop, (8) interstitial type dislocation loop, (9) precipitate. Defects (1)-(4) and (5)-(8) are called point defects and line defects, respectively.

Point defects can be categorized as intrinsic defects and extrinsic defects. For intrinsic point defects, a host atom at a certain position is missing and leaves a vacancy behind or a host atom occupies an interstitial site to form self-interstitial defect. For extrinsic point defects, the origin of this defect relates to foreign atoms which can take a lattice or interstitial site. Foreign atoms which can be introduced 
unintentionally or intentionally into the semiconductor are called impurities or solutes, respectively.

(3) (4)

(1)

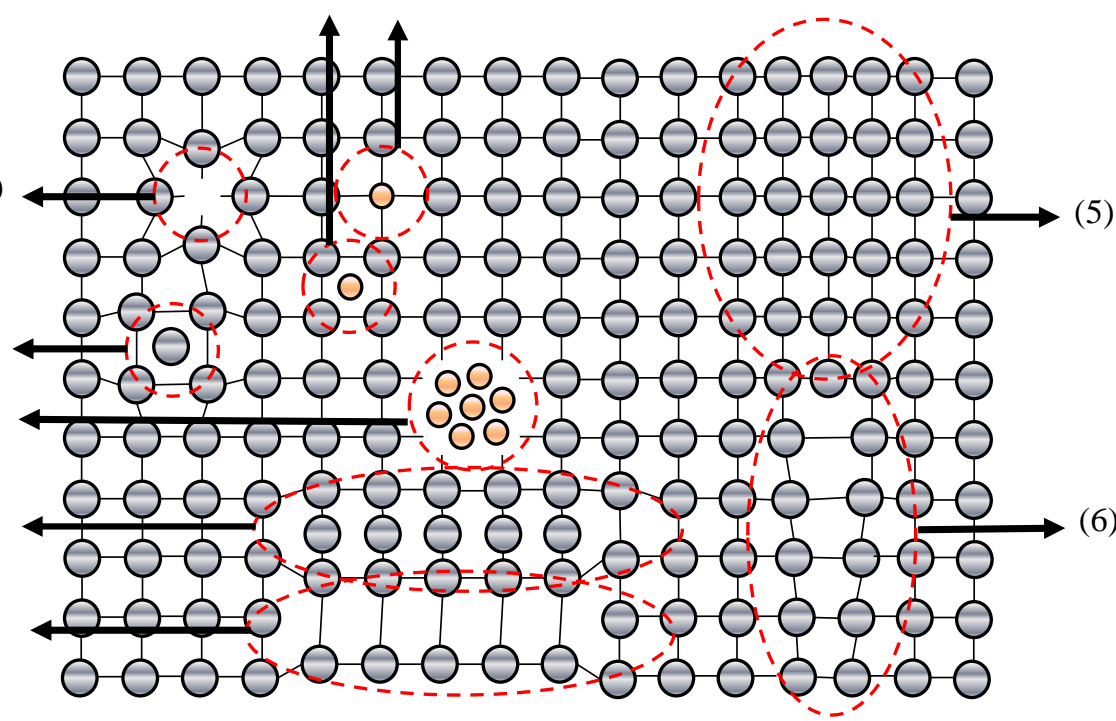

Figure 4.3. Defects in semiconductor crystal (based on [111][123])

For GaN, these defects are commonly introduced during growth process, device processing and in the working environment. Due to the lack of native substrate, $\mathrm{GaN}$ is often grown on a foreign substrate having different lattice structure. The difference in lattice constants gives rise to high threading dislocation density in GaN. Moreover, it is not possible to avoid contamination of other elements such as $\mathrm{Si}$ and $\mathrm{O}$, which is always present during growth. It is well-known that the origin of unintentional n-type GaN doping is related to the presence of $\mathrm{Si}$ and $\mathrm{O}[92]$. Process steps such as polishing or plasma etching also introduces defects in $\mathrm{GaN}$. In case of non-optimized processing, these defects appears with high density close to the surface. A third source of defects is the working environment of the GaN-based device. When the device is working in a radioactive environment such as nuclear plant or in space, the radiation can induce intrinsic defects, more details in Ref. [93]. Defects affect strongly the performance of GaNbased devices, and therefore, it is essential to understand the properties and the origin of the defects. In addition, when we understand the 
electronic properties of the defects, we can use defects to control the behavior of devices.

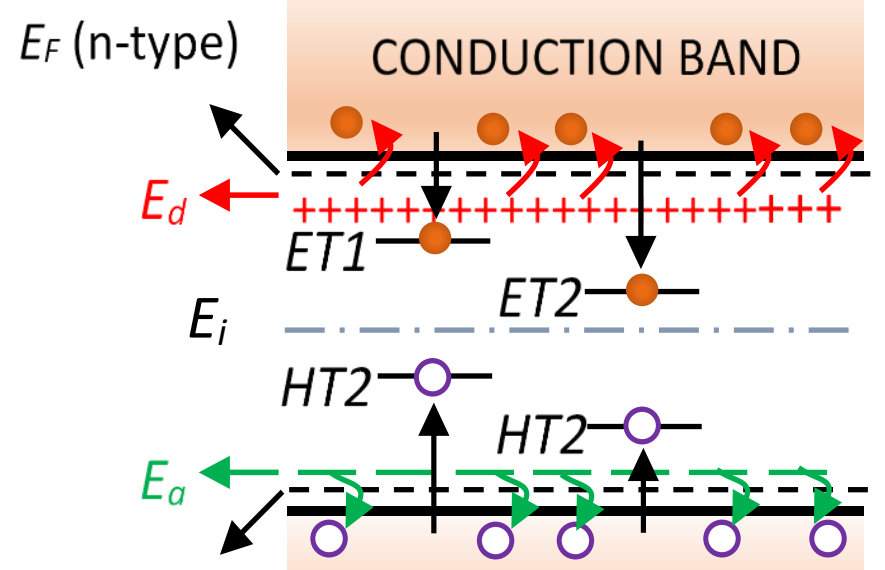

$E_{F}$ (p-type) VALENCE BAND

Figure 4.4. Band structure diagram of a doped semiconductor with deep levels

The presence of defects in GaN can form energy levels in the band gap, as shown in Fig 4.4. In the figure, $E_{i}$ is the intrinsic Fermi level, $E_{F}$ is the Fermi level of the $n$-type and $p$-type semiconductor, respectively, $E_{d}$ and $E_{a}$ are the level of donors and acceptors, respectively, and $E T$ represent an electron trap while $H T$ represent a hole trap.

The energy level close to the edge of the conduction or valence band is referred as a shallow level. Defects introducing shallow level is often used to control conductivity of semiconductors. Particularly, $\mathrm{Si}$ is used as a donor for n-type $\mathrm{GaN}, \mathrm{Mg}$ is used for p-type $\mathrm{GaN}$. Defect having its energy level deeply in the band gap is called deep level defect. Examples are $\mathrm{C}$ and $\mathrm{Fe}$ which can be used for semiinsulating GaN. Deep levels in the upper half of the band gap normally have a higher probability of capturing electrons in the conduction band whereas deep levels in the lower half of the band gap have a higher probability of capturing holes in the valence band. 


\subsection{Emission and capture of charge carriers}

The trap level can capture or emit charge carrier through the emission and capture process described by the Shockley-Read-Hall statistics [94], [95]. In semiconductor, there are two charge carriers: electron and hole so that there are four processes, which can happen as a deep level is introduced into the band gap:

(a) the capture of electrons from the conduction band

(b) the emission of electrons from the trap center

(c) the emission of holes to the valence band or the emission of electrons from the valence band to the trap center

(d) The capture of holes from the valence band.

(a)

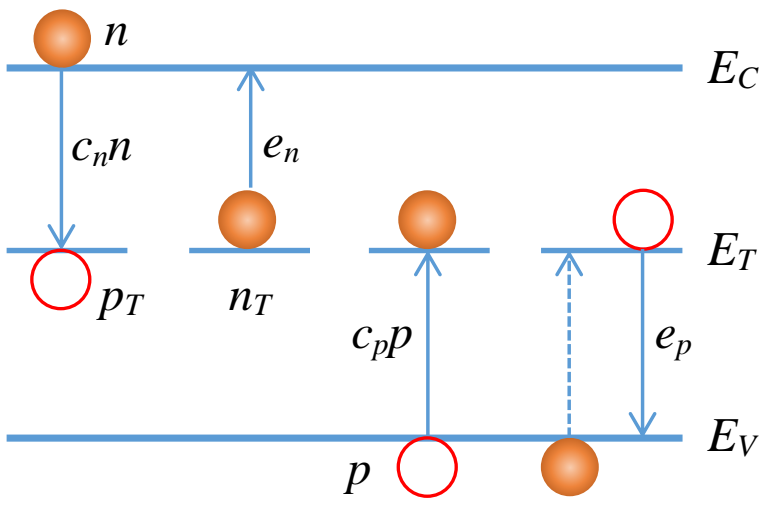

Figure 4.5. Emission and capture processes of electrons and holes at a trap level in the band gap of a semiconductor.

These processes are presented in Fig. 4.5 in which $n$ and $p$ are the concentrations of electrons and holes in the conduction band and valence band, respectively, $p_{T}$ and $n_{T}$ are the concentration of the empty trap and the filled traps, $c_{n} n$ and $c_{p} p$ are the capture rate of electron and hole, $e_{n, p}$ are the emission rate of electron and hole. $c_{n}$ and $c_{p}$ are the capture coefficient which has the unit $\mathrm{cm}^{3} / \mathrm{s}$ and is defined by:

$$
c_{n, p}=\sigma_{n, p}\left\langle v_{t h}\right\rangle
$$


where $v_{t h}$ is the thermal velocity of electron or hole, $\sigma_{n, p}$ is the capture cross-section of the deep level.

A combination of process (a) and (b) or process (c) and (d) is called a trapping process. Whereas, the generation of charge happens when the process (b) occurs followed by the process (d). Next, the recombination of electron and hole happens in case of that the process (c) occurs after the process (a), or vice versa. When the recombination and the generation occur together at the same level, the impurityinduced level is considered as a Generation-Recombination center (G$\mathrm{R}$ center). Therefore, an impurity can behave as a trap or a G-R center. For the trap case, just one band (conduction band or valence band) and the impurity participated while two bands and the impurity for the case of the G-R center.

\subsection{Emission rate}

To formulate the equation of emission rate, we start from the equation describing the rate of change of the filled trap center which is given by the difference between these two processes:

$$
\begin{aligned}
\frac{d n_{T}}{d t}=\frac{d p}{d t}-\frac{d n}{d t} & =e_{p} p_{T}-c_{p} p n_{T}-e_{n} n_{T}+c_{n} n p_{T} \\
& =\left(e_{p}+c_{n} n\right)\left(N_{T}-n_{T}\right) \\
& -\left(c_{p} p+e_{n}\right) n_{T}
\end{aligned}
$$

where $N_{T}=p_{T}+n_{T}$ is the total defect concentration, $p_{T}$ is the concentration of empty traps. By solving Eq. 4.10 in thermal equilibrium [91] with some simplifications, the electron emission rate is derived as following:

$$
e_{n}=c_{n} n \frac{g_{0}}{g_{1}} \exp \left(\frac{E_{T}-E_{F}}{k T}\right)
$$

where $g_{0}$ and $g_{1}$ are the degeneracy factors of the deep level when being empty or occupied by an electron, respectively. The electron concentration $n$ in the conduction band is determined by [96]: 


$$
n=N_{C} \exp \left(-\frac{E_{C}-E_{F}}{k T}\right)
$$

where $N_{C}$ is the effective density of states in the conduction band:

$$
N_{C}=2 M_{C}\left(\frac{2 \pi m_{e}^{*} k_{B} T}{h^{2}}\right)^{3 / 2}
$$

where $M_{C}$ is the number of conduction band minima of the semiconductor (for wurtzite $\mathrm{GaN} M_{C}=1$ ), $m_{e}^{*}$ is the effective mass of electron.

Substituting $c_{n}$ in Eq. 4.11 by using Eq. 4.9, the electron emission rate can be obtained:

$$
e_{n}=\sigma_{n}\left\langle v_{t h}\right\rangle \frac{g_{0}}{g_{1}} N_{C} \exp \left(-\frac{E_{C}-E_{T}}{k T}\right)
$$

where $\left\langle v_{t h}\right\rangle$ is the rms thermal velocity of the electron:

$$
\left\langle v_{t h}\right\rangle=\left(\frac{3 k_{B} T}{m_{e}^{*}}\right)^{1 / 2}
$$

It is convenient to rewrite the emission rate as following:

$$
e_{n}=\frac{g_{0}}{g_{1}} \sigma_{n} \gamma T^{2} \exp \left(-\frac{E_{C}-E_{T}}{k T}\right)
$$

where $\gamma=2 \sqrt{3}\left(\frac{2 \pi}{h^{2}}\right)^{\frac{3}{2}} m_{n}^{*} k^{2} M_{C}$.

\subsection{Electric field enhanced emission}

For some deep levels, the thermal electron emission is not only dependent on the temperature but also on the applied electric field which can enhance the thermal emission rate via three different mechanisms: (1) Poole-Frenkel effect [91], [97]; (2) phonon-assisted tunneling [98], [99] and (3) pure tunneling [100], as shown in Fig. 4.6. Each mechanism has an effective range of electric field: the mechanisms of (1) and (2) is dominant when the electric field is in the 
range $10^{4}-10^{6} \mathrm{~V} / \mathrm{cm}$ while the mechanism of (3) is only important at high electric fields $\left(>10^{7} \mathrm{~V} / \mathrm{cm}\right)$. Since the electric field is typically in the range $10^{4}-10^{6} \mathrm{~V} / \mathrm{cm}$ in capacitance transient studies, this section will mainly focus on mechanisms (1) and (2).

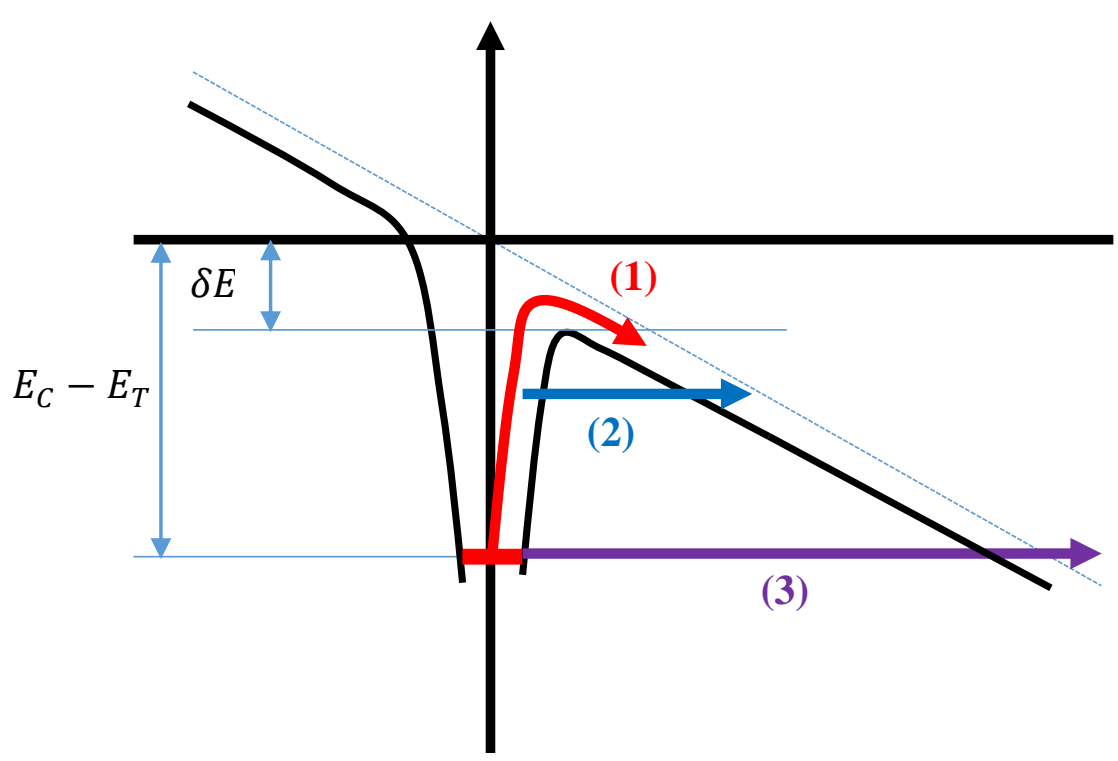

Figure 4.6. Diagram of three mechanisms of electric field enhanced emssion: (1) Poole-Frenkel emission, (2) phonon-assisted tunneling and (3) pure tunneling (based on Fig. 4.10 in [124] and Fig. 5.4 in [125])

For the Poole-Frenkel effect, there have been a couple of models suggested. The first and simplest model is proposed by Frenkel in which he used an assumption of a simple one-dimension (1D) Coulombic potential to determine the lowering of the potential $\delta E$ by an applied electric field, as shown in Eq. 4.17:

$$
\delta E=-q \sqrt{\frac{q F}{\pi \varepsilon_{r} \varepsilon_{0}}}
$$

where $q$ is the electron charge, $F$ is the electric field. In case of a diode with uniform doping, the electric field can be determined by: 


$$
\begin{gathered}
F=F_{m}\left(1-\frac{x}{W}\right) \\
F_{m}=\frac{q N_{d} W}{\varepsilon_{r} \varepsilon_{0}}
\end{gathered}
$$

where $x$ is the distance from the MS junction and $F_{m}$ is the maximum electric field in the depletion region [101].

Table 4.2. The emission rate corresponding to several different potentials for modeling the Poole-Frenkel process

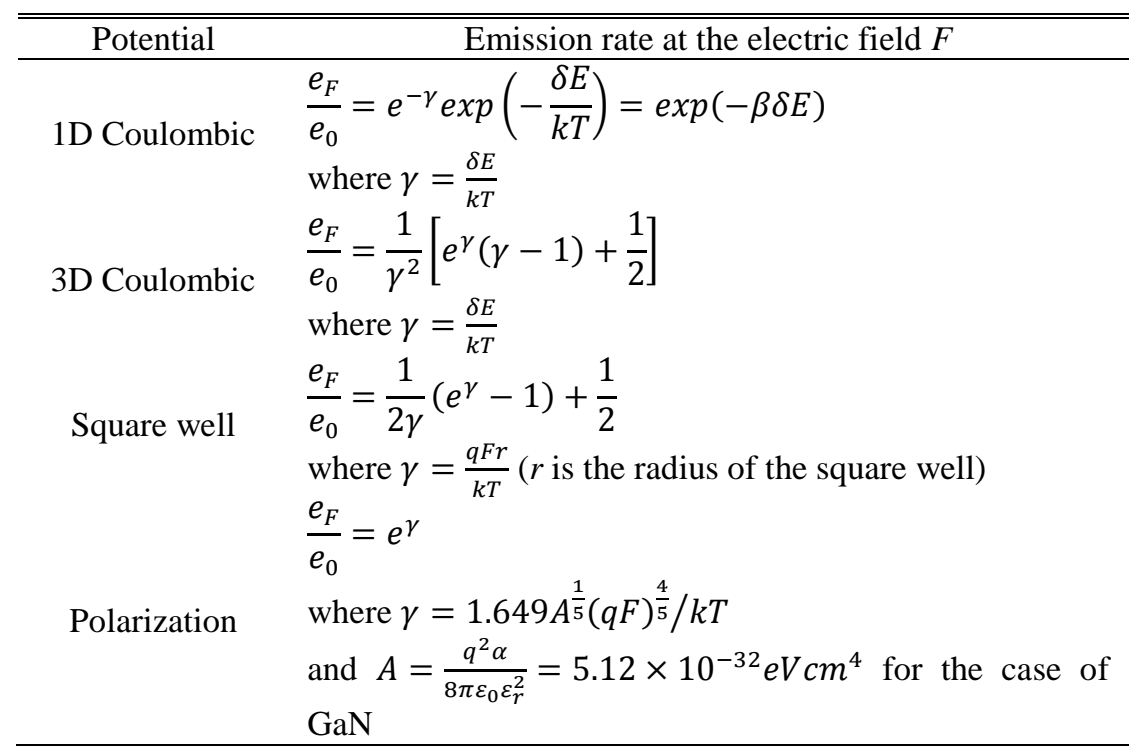

However, the first model has an issue in overestimating the electric field enhanced emission rate. Therefore, other authors used other potentials to describe the enhancement of the emission rate such as a three-dimensional (3D) Coulombic potential [102], [103], a square well potential [100], [104], [105], a polarization potential[106]. For each chosen potential, there is a corresponding equation describing the relation between the emission rate enhanced $\left(e_{F}\right)$ by the field $F$ and the emission rate without electric field $\left(e_{0}\right)$, as shown in Table 4.2.

The emission rate can be affected via a phonon-assisted tunneling process, in which the electron is excited by absorbing a phonon in a crystal and goes through the potential barrier. The emission rate in the 
case of the phonon-assisted tunneling process is presented in Ref. [48], [98], [107] in which authors used some different potentials to model the phonon-assisted process.

\subsection{Mechanism of capturing processes}

As mentioned above, defects existing in a semiconductor can introduce deep levels in the band gap. The carriers can be captured by the deep level and release its excess energy in the radiative form (emitting photon) or in the non-radiative form (such as emitting phonon). So far, there have been three suggested mechanisms of nonradiative process named as: cascade capturing process [108], multiphonon-assisted capturing process [109] and Auger capturing process [110]. Each process presents its own dependence on the temperature which is often used to determine what dominant process is governing the capture process.

\subsubsection{Cascade capture}

The cascade capturing process is mostly observed in case of shallow level defects, which form localized states. The potential of a shallow level defect can be described as a hydrogen-like potential, as shown in Fig 4.7. In this process, the carrier in the excited states jumps down to lower state, then releases its excess energy as phonons. If the distance between two states is small, the emitted phonon has its energy equal to the energy difference of two states. For the large distance, relaxation happens and more than one phonon can be emitted. The stability of a carrier in a certain state is strongly dependent on the temperature. In a condition of a high temperature, carrier can re-emit to higher excited states, making the capture probability decrease. The cascade capturing process is inversely proportional to the temperature $\left(\sim T^{x}\right)$ where the factor $x$ varying from -3 to -1 , which depends on whether optical or acoustic phonons are involved [108]. 


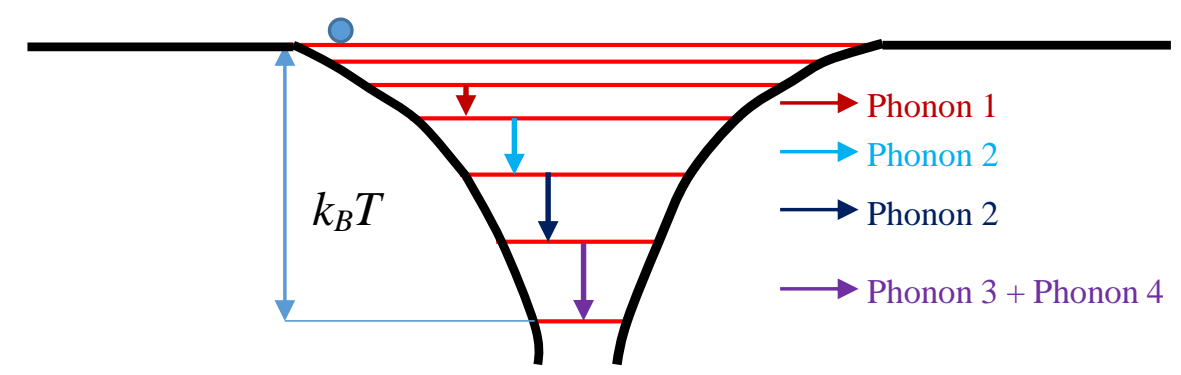

Figure 4.7. The cascade capturing process

\subsubsection{Multiphonon capture}

The multiphonon capturing process happens in the case of a strong interaction between the defect and the lattice. This process might be explained through a configuration coordinate diagram (Fig. 4.8). The equilibrium position of defects when being empty $\left(E_{e}(Q)\right)$ and filled $\left(E_{f}(Q)\right)$ is denoted as $Q^{0}$ and $Q^{-}$, respectively. The free hole states are localized at $E_{0}(Q)$. Due to a strong defect-lattice couple, the vibrations cause the empty trap level $\left(E_{t}^{0}\right)$ move up and down. If the trap level crosses the conduction band, it can capture electron in this band and be excited. After the relaxation process with phonon emission, the defect will have a new equilibrium position at $Q^{-}$. Similar to the case of electron capturing process, the hole capturing process happens when the filled trap level $\left(E_{t}^{-}\right)$vibrates around its equilibrium position $Q^{-}$until it crosses the valence band. Therefore, the trap level in this case can be considered as the recombination center.

In this case, the capture cross section of defects is strongly dependent on temperature. The capture cross section can is described with an exponential function [109]:

$$
\sigma_{T}=\sigma_{T \rightarrow \infty} \exp \left(-\frac{E_{b}}{k T}\right)
$$

where $\sigma_{T \rightarrow \infty}$ is the capture cross section as $T \rightarrow \infty, E_{b}$ is the cross section activation energy required to overcome the thermal barrier for electron and hole $\left(E_{b}^{n}\right.$ and $\left.E_{b}^{p}\right)$ capturing. 


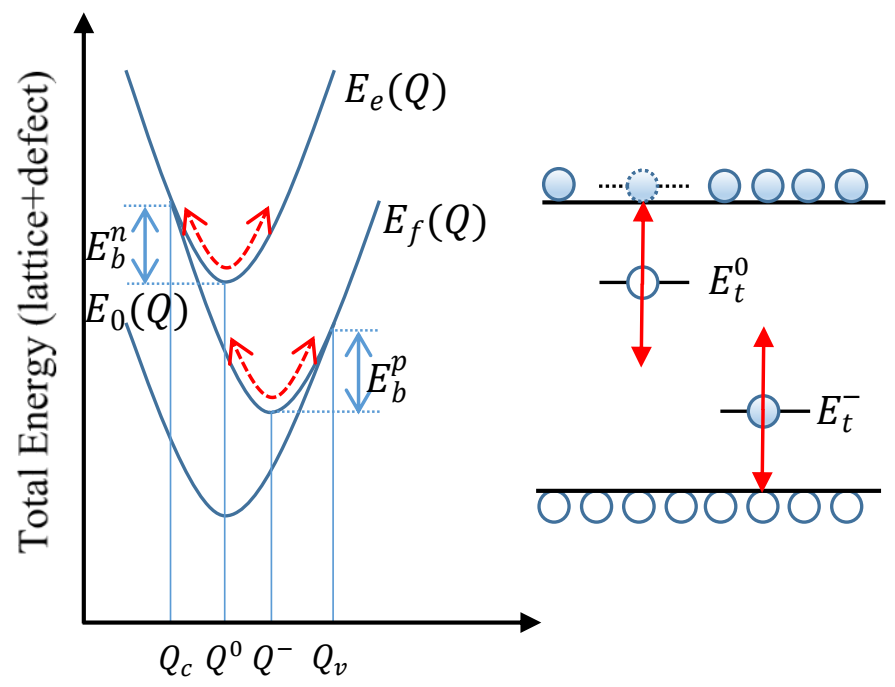

Generalized coordinate

Figure 4.8. Configuration coordinate diagram and band diagram which present the multiphonon capturing process

\subsubsection{Auger capture}

In Auger capturing process, the capture cross section mainly depends on the charge carrier concentration. The charge carriers can interact each other and transfer their excess energy to a neighbor electron or hole. The excited carrier (electron or hole) is not stable and quickly relaxes to the low and more stable state by emitting photons or phonons. Therefore, this process is influenced by the thermal distribution of the carrier concentration.

\subsection{Capacitance transient spectroscopy}

The principle of capacitance transient spectroscopy (CTS) is to study the change of capacitance as the function of time when the charge density in depletion region changes. Fig. 4.9 shows the principle of CTS in details on an n-type Schottky diode with one electron trap level. In the first stage, (Fig. 9(a)) the Schottky diode is under a reversed bias which means that there is no free charge carriers 
in the space charge region, and all traps are empty of electrons. The second stage (Fig. 4.9(b)) is that the reverse bias is decreased (a filling pulse is applied). Free electrons will diffuse from the neutral region and trap levels below the Fermi level will capture electrons. In this stage, the electron capturing process is dominant compared to the thermal emission process. In the third stage (Fig. 9(c)), we restore the reverse bias, and electrons captured to traps during the filling pulse will start to emit electrons due to thermal emission. Since the charge density in the depletion region is changing due to the emission of electrons, the width of the depletion region decreases (in case of electron traps in n-type material). The change of depletion region can be monitored by the capacitance changes as a function of time according to [111]:

$$
C(t)=C_{r}\left[1-\frac{n_{T 0}}{2 N_{D}} \exp \left(-\frac{t}{\tau_{e}}\right)\right]
$$

where $n_{T 0}$ is the density of filled traps at $t=0, C_{r}$ the capacitance of the diode when all traps are empty at $V_{r}, \tau_{e}$ is the emission time constant, and $\tau_{e}=\frac{1}{e_{n}}$ where $e_{n}$ is the emission rate.
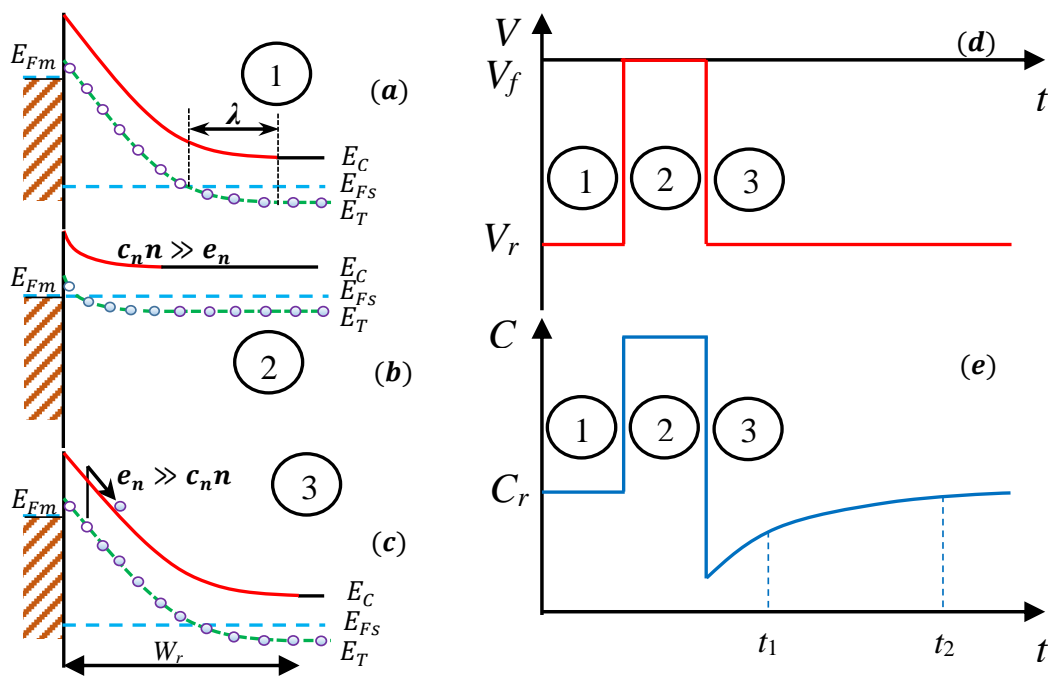

Figure 4.9. Band diagram of a Schottky diode for (a) reverse bias, (b) zero bias, (c) reverse bias at $t=0$, the applied voltage on a Schottky diode (c) and the capacitance behaviour of a Schottky diode (e) 


\subsection{Deep level transient spectroscopy}

Deep level transient spectroscopy which was introduced by Lang [112] in 1974 is the most powerful and widely used capacitance transient technique in characterization of electrically active traps in semiconductors. In principle, this technique is based on capacitance transient mentioned in Section 4.8. DLTS is also called as a correlation technique in which the signal is built by multiplying the capacitance transient with a reference signal known as the weighting function $\left(F_{c o r r}(t)\right)$ and then being integrated.

$$
S=\frac{1}{T} \int_{o}^{T} C(t) F_{c o r r}(t) d t
$$

where $T$ is the period of the weighting function. By doing this the signal-to-noise can be improved, and we can determine traps having low concentration. The simplest case of weighting function has the form:

$$
F_{\text {corr }}(t)=\delta\left(t-t_{1}\right)-\delta\left(t-t_{2}\right)
$$

where $\delta\left(t-t_{i}\right)$ is the Kronecker delta and $t_{1}$ and $t_{2}$ two different time points, as shown in Fig. 4.9. Solving Eq. 4.22 with the weighting function of Eq. 4.23 and noticing that $T=t_{2}-t_{1}$, the DLTS output signal is:

$$
S=C\left(t_{2}\right)-C\left(t_{1}\right)
$$

The two different time points define something that is called the rate window. The emission rate from the trap is temperaturedependent, and therefore, the time constant of the capacitance transient. When the traps emission rate corresponds to the rate window, the DLTS signal $S(T)$ will show a peak as shown in Fig. 4.10. Actually, the rate window contains information about the emission rate which is chosen as a reference value.

When substituting $C(t)$ in Eq. 4.24 by Eq. 4.21, the DLTS output is:

$$
S(t)=C_{r} \frac{n_{T 0}}{2 N_{D}}\left[\exp \left(-\frac{t_{2}}{\tau_{e}}\right)-\exp \left(-\frac{t_{1}}{\tau_{e}}\right)\right]
$$


In order to to get the condition for the maximum of the peak amplitude (the extreme point), differentiation of $S(t)$ with respect to $\tau_{e}$ is used:

$$
\frac{d S(t)}{d \tau_{e}}=C_{r} \frac{n_{T 0}}{2 N_{D} \tau_{e}^{2}}\left[t_{2} \exp \left(-\frac{t_{2}}{\tau_{e}}\right)-t_{1} \exp \left(-\frac{t_{1}}{\tau_{e}}\right)\right]=0
$$

Solving Eq. 4.26, the relationship between $\tau_{e(\max )}$ and the rate window is obtained:

$$
\tau_{e(\max )}=\frac{t_{1}-t_{2}}{\ln \left(\frac{t_{1}}{t_{2}}\right)}
$$

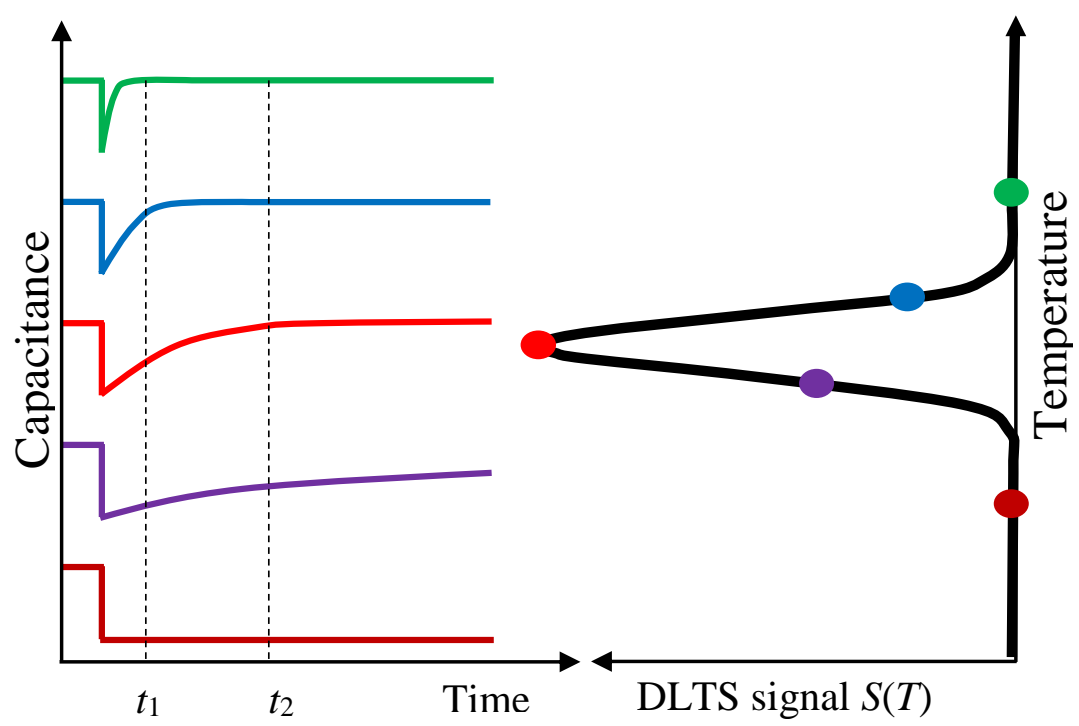

Figure 4.10. The DLTS spectrum obtained from analysis of the capacitance transients

Therefore, by choosing the rate window, it is possible to determine the emission rate through the time constant. Each emission rate corresponds to a certain temperature at which the DLTS peak occurs. By varying the sampling time $t_{1}$ and $t_{2}$ so that the reference constant time changes, a series of DLTS spectra can be obtained in which the DLTS peak move to the left (lower temperature) or the right (higher temperature), corresponding to an increase or decrease of the reference constant time, respectively. 


\subsection{Output parameters of DLTS measurements}

\subsubsection{Activation energy}
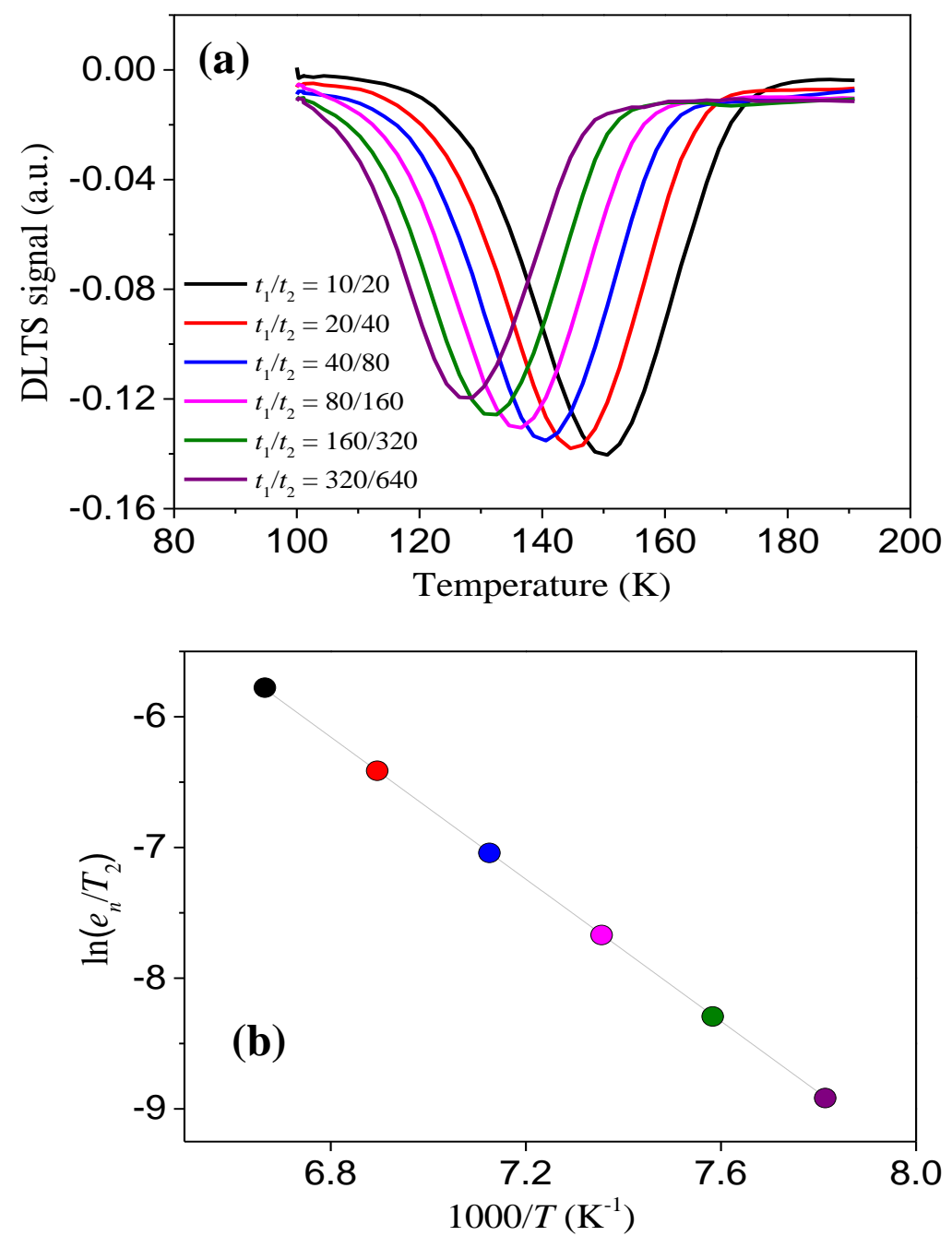

Figure 4.11. (a) a series of the DLTS spectra corresponding to different rate windows and (b) the Arrhenius plot derived from the DLTS spectra.

When characterizing defects, one important parameter is the activation energy, which is the thermal energy needed to empty the trap. The way of determining the activation energy is based on Eq. 
4.16. After taking the natural logarithm of the expression can be written as:

$$
\ln \left(\frac{e_{n}}{T^{2}}\right)=\ln \left(\frac{g_{0}}{g_{1}} \sigma_{n} \gamma\right)-\frac{E_{C}-E_{T}}{k T}=\ln \left(\frac{g_{0}}{g_{1}} \sigma_{n} \gamma\right)-\frac{E_{A}}{k T}
$$

From Eq. 4.28, it is possible to extract the activation energy by using a semi-logarithmic plot of $\ln \left(\frac{e_{n}}{T^{2}}\right)$ versus $\left(\frac{1000}{T}\right)$, named an Arrhenius plot. To construct the Arrhenius plot, a series of DLTS spectra is obtained by changing the window rate. An example is shown in Fig. 4.11(a). Next, the temperature of each peak minima/maxima and the corresponding emission rate is plotted in an Arrhenius plot, shown in Fig. 4.11(b). By linear fitting using Eq. 4.28, we can determine the activation energy $E_{A}$ and a rough estimate of the capture cross section $\sigma_{n}$.

\subsubsection{Capture cross-section}

The relationship between the emission rate and the capture crosssection in Eq. 4.28 is commonly used to determine capture crosssection. By finding the intercept of the Arrhenius plot and the vertical axis, the capture cross section is obtained. However, the capture crosssection derived from Eq. 4.28 is not very accurate because it does not take into account of the dependence of the emission rate on the Gibb energy. Thus, the intercept point actually gives a value of $\sigma_{n, \text { effective }}=\sigma_{n} \exp \left(\frac{\Delta S}{k}\right)$ which means that the value from Eq. 4.28 is only a rough estimate of the capture cross-section. To get the accurate capture cross-section, the value from Eq. 4.28 has to be divided by the term of $\exp \left(\frac{\Delta S}{k}\right)$. In many cases, the capture crosssection is dependent on temperature, which makes the situation even more complex. In many capturing processes, the capture cross-section can be described by the relationship below [109]:

$$
\sigma_{n}=\sigma_{T \rightarrow \infty} \exp \left(-\frac{E_{a \sigma}}{k T}\right)
$$

where $\sigma_{T \rightarrow \infty}$ is the capture cross-section when the temperature goes to infinity and $E_{a \sigma}$ is the capture cross-section barrier. Consequently, Eq. 
4.16 can be rewritten in the form which the dependence of the emission rate on the Gibbs free energy and the temperature, more details of description is presented in Ref. [111]:

$$
e_{n}=\frac{g_{0}}{g_{1}} \sigma_{T \rightarrow \infty} \exp \left(\frac{\Delta S}{k}\right) T^{2} \exp \left(-\frac{\Delta H+E_{a \sigma}}{k T}\right)
$$

where $\Delta S$ and $\Delta H$ are the entropy and the enthalpy, respectively.

Even if the method using the intercept point for evaluation does not give the exact value; it has been widely used in many reports for estimating a rough value of $\sigma_{n}$.

In order to get a more accurate estimate of $\sigma_{n}$, a technique suggested by Criado et. al. [113] can be used. In this technique, the DLTS peak amplitude is measured as the function of different filling pulse width. By using very short filling pulses, all traps will not have time to capture carriers, and we will therefore only get a DLTS signal from filled traps. By plotting the DLTS amplitude as a function of the filling pulse width, we can determine the capture cross-section. Depending on what kind of the defect (point defect or extended defect), the relationship between the DLTS signal and the filling pulse width is written as below:

For point defect [114-116]:

$$
S_{\text {peak }}\left(t_{f}\right)=S_{1}\left[1-\exp \left(-\sigma_{n} n\left\langle v_{t h}\right\rangle t_{f}\right)\right]+S_{2} \ln \left(S_{3} t_{f}\right)
$$

where $S_{\text {peak }}\left(t_{f}\right)$ is the DLTS peak corresponding to the filling pulse width $t_{f}, S_{1}, S_{2}$ and $S_{3}$ are the parameters in which $S_{1}$ is related to the trap concentration, $S_{2}$ and $S_{3}$ are related to the free carrier tail. These three parameters are determined by fitting the function of $S_{\text {peak }}$ versus $t_{f}$ by using Eq. (4.31).

For extended defect [114], [115], [117]:

$$
S_{\text {peak }}\left(t_{f}\right)=S_{4} \ln \left(t_{f}\right)
$$

where $S_{4}$ is determined by fitting. 


\subsubsection{Trap concentration}

Another important parameter is the trap concentration. This information is quite straight forward to obtain from the DLTS spectrum since the peak amplitude of the defect is proportional to the trap concentration. However, the DLTS technique is just suitable for the trap concentration much less than the donor concentration. The trap concentration can be calculated by [111]:

$$
N_{T}=\frac{\left|S_{\text {peak }}\right|}{C_{r}} \frac{2 r^{\frac{r}{r-1}}}{1-r} N_{d}
$$

Where $S_{\text {peak }}$ is the amplitude of the DLTS peak and $r=t_{2} / t_{1}$. Eq. 4.33 is only valid if the filling pulse is long enough to fill all defects in the investigated part of the depletion region.

The obtained trap concentration can be affected by the free carrier tail which is located at the edge of the depletion region, where the free carrier concentration is gradually decreasing. The free carrier tail region extends a distance of $\lambda$ from the edge of the depletion region to the point at which the Fermi level crosses the trap level $\left(E_{F}=E_{T}\right)$. The width of this region in steady state is given by [118]:

$$
\lambda=\sqrt{\frac{2 \varepsilon_{r} \varepsilon_{0}}{q^{2} N_{d}}\left(E_{F}-E_{T}\right)}
$$

With increasing depth of the trap level, the transition region will increase. In the case of small reverse biases, the transition region will have a larger influence on the accuracy of the DLTS measurement, particularly, the trap concentration calculated from the DLTS spectrum. In that case, it is necessary to add a $\lambda$-related correction. However, the transition region can be neglected when the depletion width is much larger than the transition region.

In the case of taking into account of the influence of the free charge carrier tail, the equation for calculating the trap concentration needs to be modified. If we assume that the depletion widths caused by a reverse bias and a filling voltage are $W_{r}$ and $W_{f}$, respectively, only the traps in the region of $\left(W_{r}-\lambda\right)$ and $\left(W_{f}-\lambda\right)$ are monitored by the DLTS method. Thus, the real trap concentration now is given by: 


$$
N_{T, r e a l}=\frac{W_{r}^{2}}{\left(W_{r}-\lambda\right)^{2}-\left(W_{f}-\lambda\right)^{2}} N_{T}
$$

\subsubsection{Depth profile}

Another advantage of DLTS is an ability to obtain the concentration profile of deep levels. This relies on the bias dependence of the depletion width where deep levels exist. In early time, the constant voltage technique was often used for trap profiling in which a constant reverse bias was applied to the diode at a temperature where the capacitance transient associated to the trap could be observed. By changing the filling pulse height, the filling depth is changed and the capacitance transient is also changed. The small change of $\delta V$ results in the change of $\frac{\delta C}{C}$, where $C$ is the capacitance of the diode at the fixed reverse bias. The relationship of $\frac{\delta C}{C}$ and $\delta V$ in the case of asymmetric junction is presented as below [91], [119]:

$$
\frac{\delta C}{C}=\frac{\varepsilon_{r} \varepsilon_{0} N_{T}(x)}{q W^{2} N_{d}(W) N_{d}(x)} \delta V
$$

where $W$ is the depletion width formed by the fixed reversion bias, $\mathrm{x}$ is the depletion width during the filling pulse, $N_{T}$ and $N_{d}$ are the trap concentration and the net donor concentration, respectively.

One problem with the constant voltage technique is when the carrier emission rate of the deep level depends on the electric field (field enhanced emission). To address this issue, a modified technique, named the double correlation DLTS technique (DDLTS)[120], was proposed by Lefèvre and Schulz in 1977. By using this technique, one can determine the trap concentration in a small region of the depletion width in which the electric field can be considered as constant. The principle is described in Fig. 4.12, in which there are two filling pulses with different amplitudes, labelled $V_{p 1}$ and $V_{p 2}\left(V_{p 1}>V_{p 2}\right)$, are used. For each pulse, a capacitance transient is observed and acquired by the capacitance meter connected to the computer. If we denote $C_{1}\left(t, V_{p 1}\right)$ and $C_{2}\left(t, V_{p 2}\right)$ as the capacitance transient corresponding to the filling 
pulse $V_{p 1}$ and $V_{p 2}$, the signal of DDLTS is determined as the following equation:

$$
\Delta C\left(t, V_{p 1}, V_{p 2}\right)=C_{1}\left(t, V_{p 1}\right)-C_{1}\left(t, V_{p 2}\right)
$$
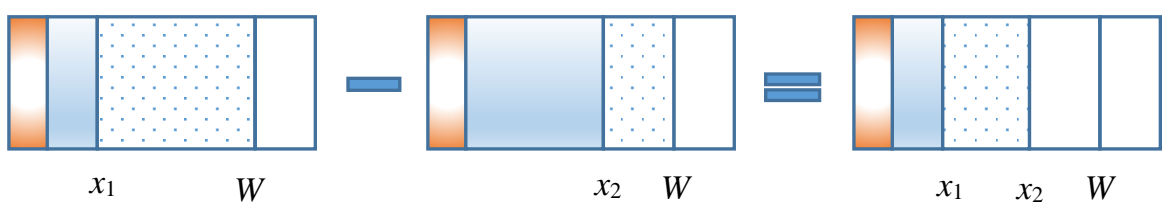

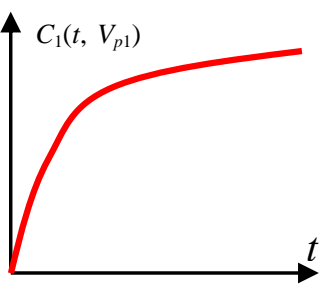

(a)

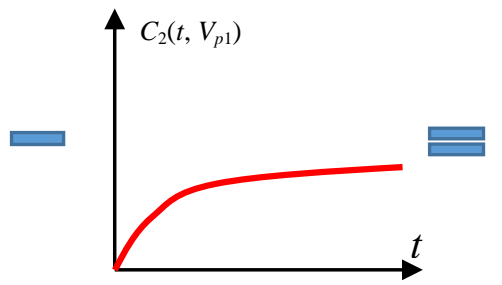

(b)

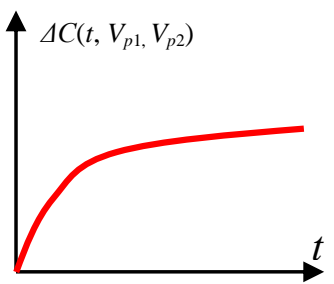

(c)

Figure 4.12. The depletion region and the capacitance transient: (a) when applying the filling pulse $V_{p 1}$, (b) when applying the filling pulse $V_{p 2}$ and (c) when subtracting the case (b) from the case (a). The brown region is the Schottky contact, the blue region is the depletion region, the dotted region is the analyzed region and the white region is the neutral region.

Therefore, the signal of $\Delta C\left(t, V_{p 1}, V_{p 2}\right)$ contains important information of traps in the region limited between $x_{1}$ and $x_{2}$ formed during the filling pulse of $V_{p 1}$ and $V_{p 2}$, as shown in Fig. 4.13. If $x_{1}$ is not much larger than $x_{2}$, the electric field in the analysed region can be considered as constant. In order to get the depth profile of a certain trap, the diode should be fixed at the temperature corresponding to the DLTS peak of the trap. The DDLTS signals are then collected by scanning the reverse bias $V_{r}$ while $\left(V_{r}-V_{p 1}\right)$ and $\left(V_{r}-V_{p 2}\right)$ are unchanged. Finally, the trap concentration is calculated by the below equation[91]:

$$
N_{T}\left(x_{2}\right)=\frac{2\left(\varepsilon_{r} \varepsilon_{0} A\right)^{2}}{C_{r}^{3}\left[x_{2}^{2}-x_{1}^{2}\right]} \Delta C \cdot N_{d}(W)
$$


where $A$ is the contact area, $C_{r}$ is the capacitance of the diode when applying the reverse bias, $\Delta C=\Delta C_{1}-\Delta C_{2}$ where $\Delta C_{1}, \Delta C_{2}$ are determined as in Fig. 4.13.

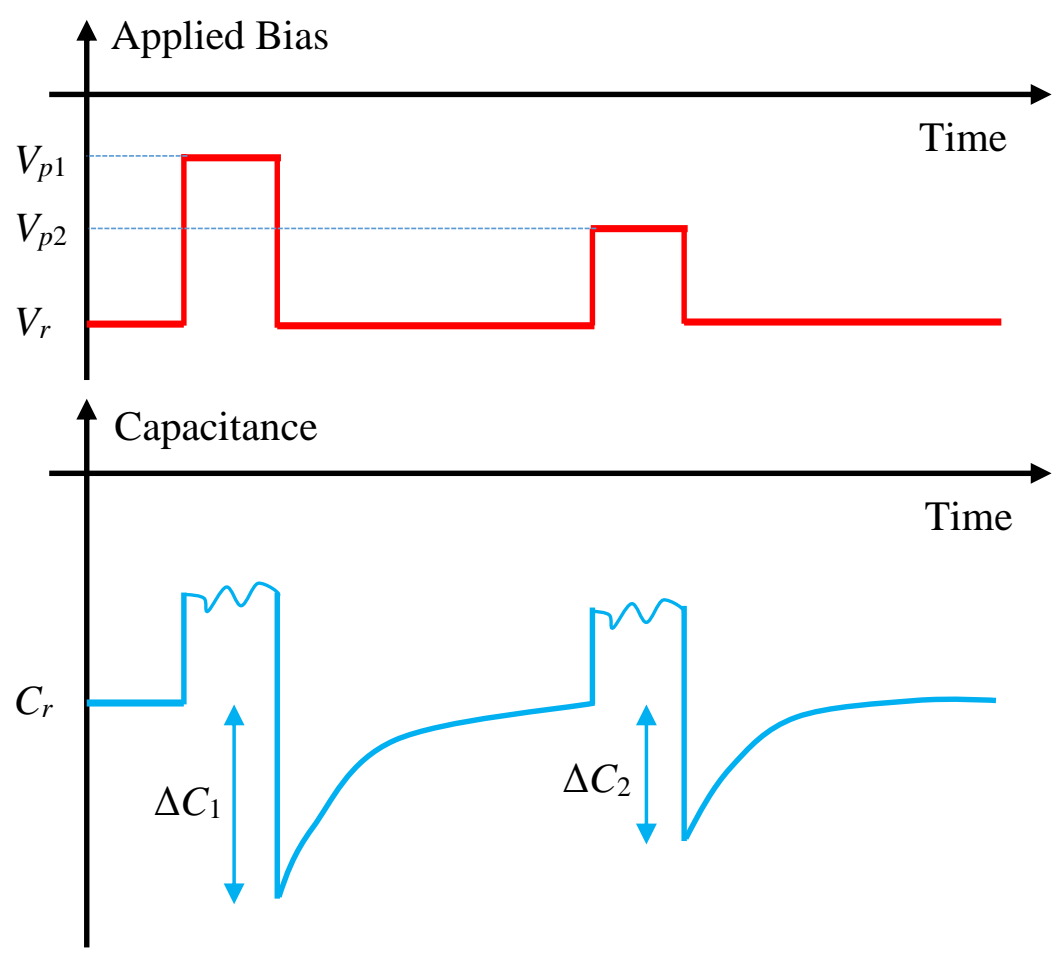

Figure 4.13. Diagram of the applied bias and the capacitance transient in the DDLTS technique.

\subsection{Minority carrier transient spectroscopy}

By using conventional DLTS technique on Schottky diodes, one can only study traps capturing majority carriers and not minority carrier, i.e. we can only detect electron traps in n-type material and hole traps in p-type material. In order to characterize minority carrier traps, a common technique known as minority carrier transient spectroscopy (MCTS) [122] is often used. In this technique, minority carriers are injected into the depletion region by light pulses. The minority carriers is created when the light pulse excite electrons from the valence band to the conduction band. In most cases, the light is applied from the front of the sample, and therefore, the Schottky 
contact must have the ability to transmit light. In this thesis, the thickness of the Schottky contacts is varied in range of 15-30 nm which is thin enough for both making bonding and transmitting light.

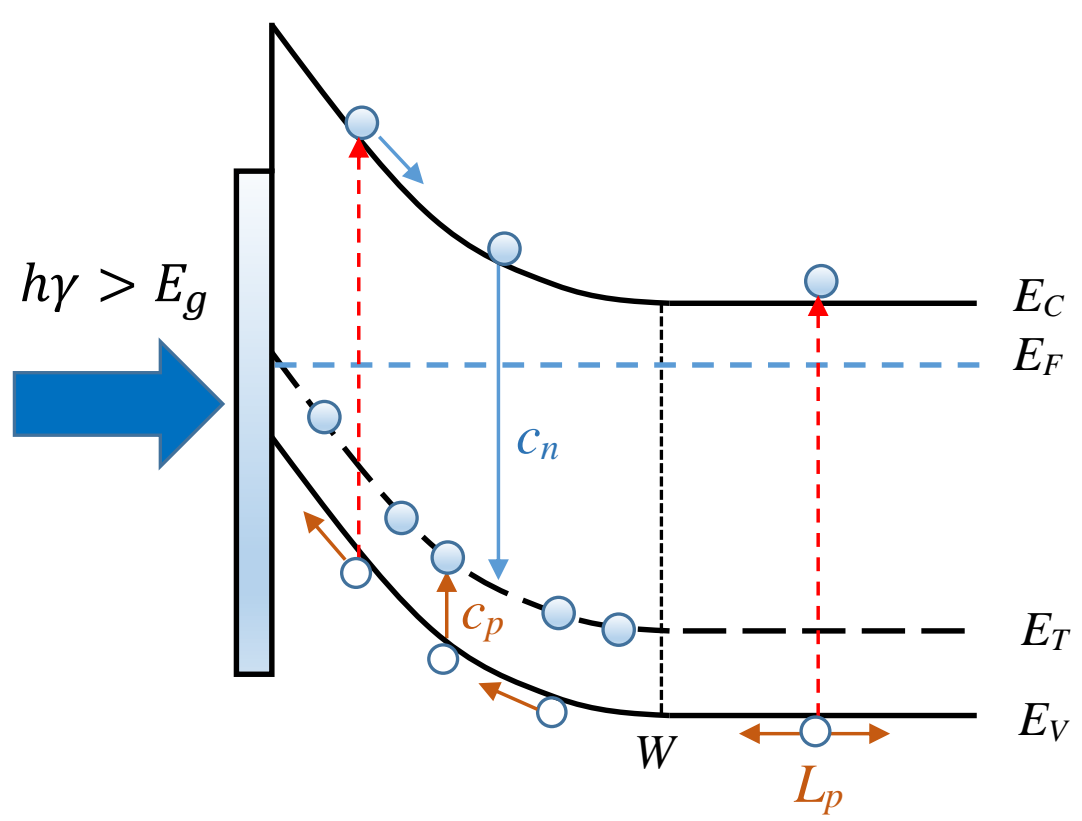

Figure 4.14. Band diagram of a Schottky contact on n-type semiconductor when illuminated by light with energy exceeding the bandgap. Holes diffuse and drift into the depletion region while electrons drift out of the depletion region.

Fig. 4.14 shows the principle of the MCTS technique. When illuminating the contact with light having an energy that exceeds the bandgap, electron-hole pairs are created in both the neutral and the depletion region. Due to the bending, majority carrier (electrons in this case) is rapidly swept out of the depletion region and forms an electron drift current while the minority carrier is injected into the depletion region through the two mechanisms: drift and diffusion.

The sample characterized by MCTS technique needs to be fulfilled two conditions: the diffusion length is long, and the absorption distance exceeds the depletion width. The absorption distance $\alpha^{-1}$ is a very important parameter and is used for determine the generation rate of electron-hole pairs, $G$, according to [91]: 


$$
G=\alpha T \phi_{0} \exp (-\alpha x)
$$

where $\alpha$ is the absorption coefficient, $T$ is the transparency of the contact, $\phi_{0}$ is the photon flux and $x$ is the distance from the contact interface.

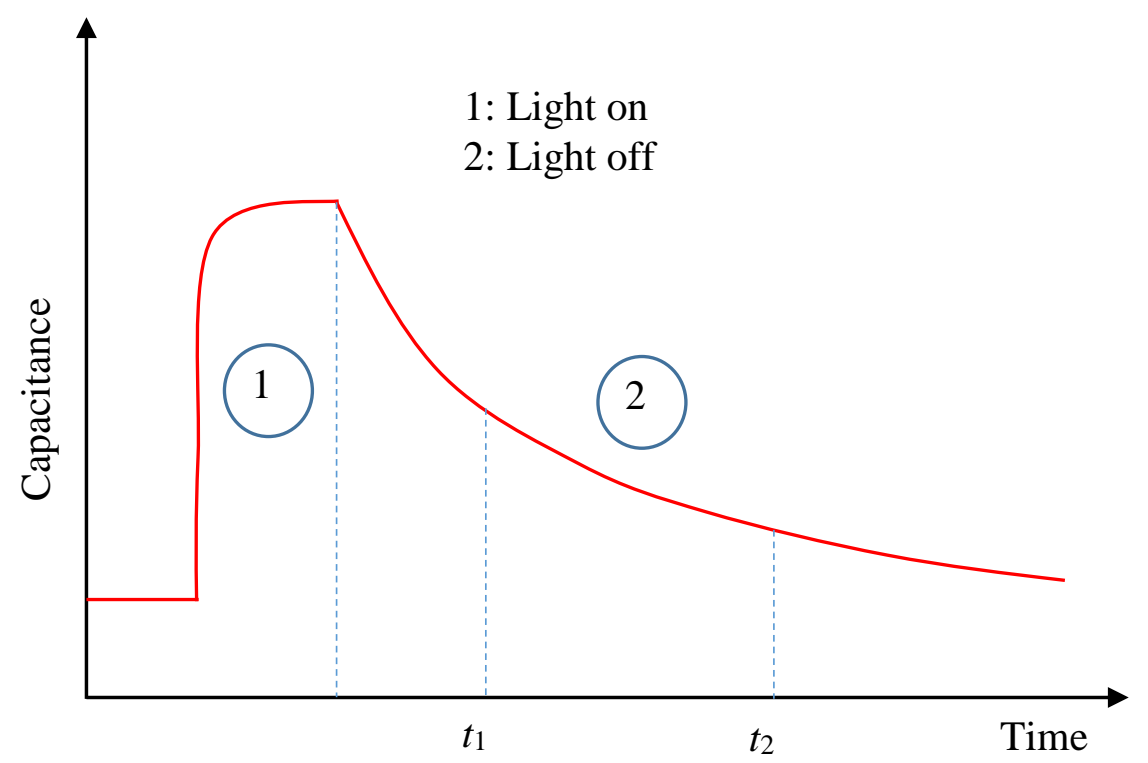

Figure 4.15. Capacitance transient in the MCTS technique.

Similar to DLTS, in order to build MCTS spectrum, one should acquire the capacitance transient. In MCTS, the diode is kept at a constant reverse voltage and optical pulse is used to inject minority charge carriers into the depletion region instead of the electrical pulse as in DLTS. To control the time of pulse, a shutter with the opening time in the range of $10 \mathrm{~ms}$ to $999 \mathrm{~ms}$ has been used. After the light has been shut off, the change of capacitance is monitored by a capacitance meter and record by an analog to digital converter and stored in a computer. Fig. 4.15 shows the change of capacitance during one period of the optical pulse. The capacitance transients are analyzed with the same technique as for DLTS. 


\section{OTHER ELECTRICAL CHARACTERIZATION TECHNIQUES}

\subsection{Current - voltage measurement}

A high diode leakage current in capacitance transient studies can cause serious error in the analysis of the data. The peak amplitude will be reduced, which results in an erroneous defect concentration and the peak position can shift which gives errors in the activation energy and the capture cross section [121]. For this reason, the Schottky diode need to be characterize carefully by current-voltage (IV) measurement to choose a good diode used for the measurements. All samples used in this thesis fulfill the requirement of a leakage current below $10 \mu \mathrm{A}$ [91].

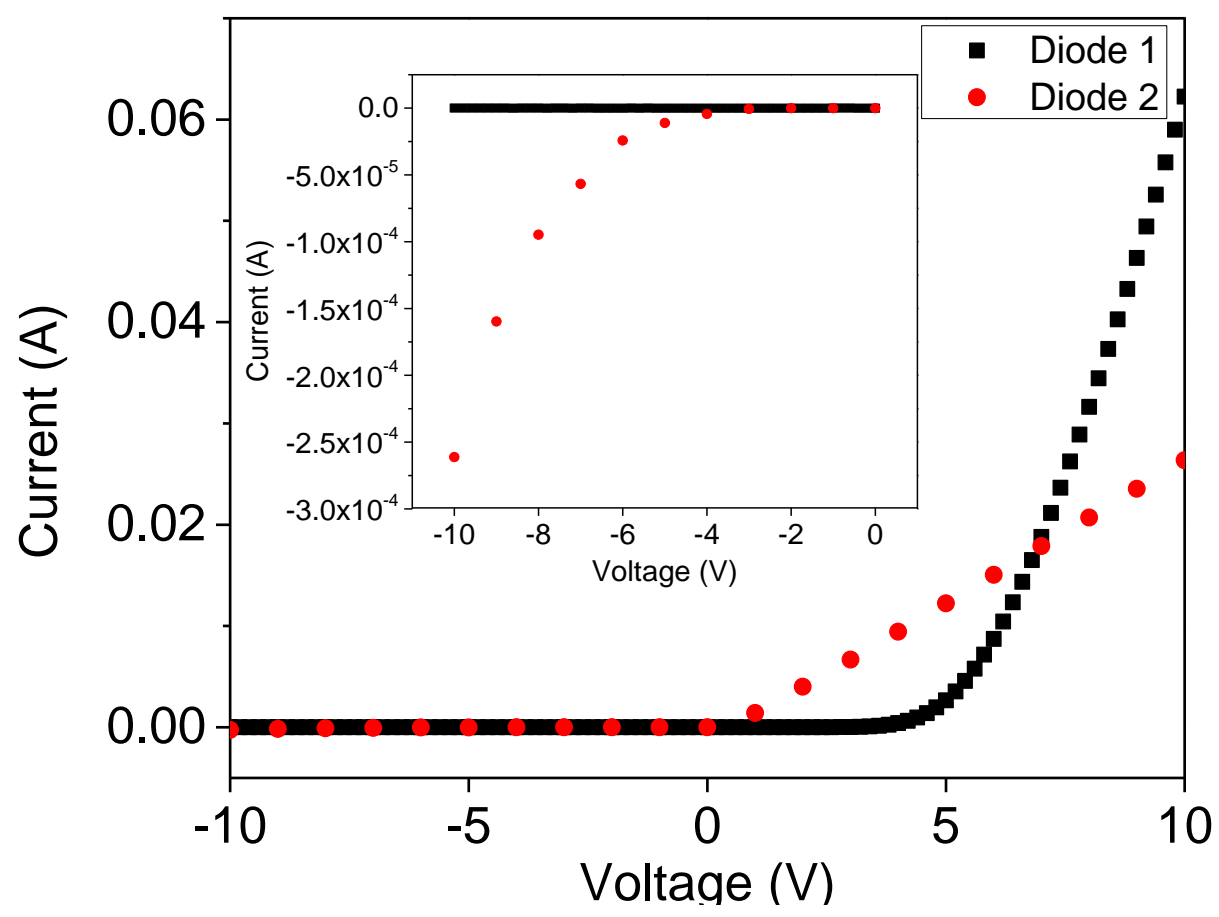

Figure 5.1. Current-voltage measurement of two different Schottky diodes in the range of $-10 \mathrm{~V}$ to $10 \mathrm{~V}$, the insert shows the scaled up range of $-10 \mathrm{~V}$ to $0 \mathrm{~V}$. 
Fig. 5.1 shows the IV data of two Schottky diodes which demonstrates rectifying properties. However, only one of them fulfills the requirement for carrying out DLTS measurements (diode 1). Diode 2 is not good for DLTS measurements because the leakage current at $-10 \mathrm{~V}$ is too high $(>250 \mu \mathrm{A})$ and the series resistance is very large. This can seriously affect the accuracy of the parameters obtained from DLTS.

\subsection{Capacitance - voltage measurement}

$C V$ measurement is used for determining the net doping concentration which is an important parameter needed to calculate the trap concentration in the depletion region. In principle, the capacitance of the depletion region is related to the net doping concentration, which is considered as the donor concentration in the case of n-type GaN, through Eq. 5.1 [91]:

$$
\frac{1}{C^{2}}=\frac{2 V}{A^{2} \varepsilon_{r} \varepsilon_{o} q N_{d}}=\frac{2\left(V_{r}+V_{i}\right)}{A^{2} \varepsilon_{r} \varepsilon_{o} q N_{d}}
$$

where $A$ is the area of the contact, $C$ is the capacitance, $N_{d}$ is the net donor concentration, $\varepsilon_{r}, \varepsilon_{o}$ are the relative permittivity (also called electric constant, $\left.\varepsilon_{r}(G a N)=8.9\right)$, the vacuum permittivity $\left(\varepsilon_{0}=\right.$ $\left.8.86 \times 10^{-12} \mathrm{~F} / \mathrm{m}\right)$, respectively, $V$ is total voltage, $V_{r}$ is the reverse bias, $V_{i}$ is the built-in potential and $q$ is the elementary charge. From Eq. 5.1, the slope of the $1 / C^{2}$ versus $V$ plot contains information of the donor concentration. Therefore, one can easily calculate not only the donor concentration but also the built-in potential by extrapolating the line to the crossing point of the voltage axis. 


\section{SUMMARY OF PAPERS}

\section{Defects in as-grown HVPE grown GaN.}

In paper 1, we have studied deep levels in free-standing $\mathrm{GaN}$ grown by halide vapor phase epitaxy using DLTS. Six electron traps were observed: $E_{1}\left(E_{C}-0.25 e V\right), E_{2}\left(E_{C}-0.53 e V\right), E_{3}\left(E_{C}-0.69 \mathrm{eV}\right), E_{4}$ $\left(E_{C}-0.65 \mathrm{eV}\right), \mathrm{E}_{5}\left(\mathrm{E}_{\mathrm{C}}-1.4 \mathrm{eV}\right)$, and $\mathrm{E}_{6}\left(\mathrm{E}_{\mathrm{C}}-1.55 \mathrm{eV}\right)$. Among the observed levels, trap $\mathrm{E}_{6}$ has not been previously reported. The filling pulse method was employed in order to determine the temperature dependence of the capture cross section and to distinguish between point defects and extended defects. The capture cross-section of traps $E_{1}, E_{2}, E_{4}$ were temperature independent in the measured temperature range. From the electron capture behavior, it is suggested that these traps are associated with point defects. From the defect concentration profile obtained by DDLTS, it is suggested that trap $\mathrm{E}_{4}$ and $\mathrm{E}_{6}$ are introduced by the polishing process.

\section{Defects in MOCVD grown Mg-doped GaN.}

Hole and electron traps in Mg-doped MOCVD grown GaN was studied in paper 2 using DLTS and MCTS. Two traps are revealed in the investigated temperature range. In the substrate, one electron trap labelled ET1 $\left(\mathrm{E}_{\mathrm{C}}-0.16 \mathrm{eV}\right)$ is observed and in the Mg-doped layer, one hole trap labelled HT1 has been revealed. By varying the electric field, it is found that the hole trap HT1 exhibits an electric field enhanced hole emission rate. Using four theoretical models based on 3-dimensional Coulombic Poole-Frenkel effect, 3-dimensional square well Poole-Frenkel effect, phonon assisted tunneling, and 1dimensional Coulombic Poole-Frenkel effect including phonon assisted tunneling, the experimental data are fitted in order to justify the field enhanced emission process. It is found that the 1-dimensional Coulombic Poole-Frenkel model including phonon assisted tunneling is consistent with the experimental data. Since the trap exhibits PooleFrenkel effect, we suggest it is acceptor like. From the theoretical model, the zero field activation energy of HT1 and an estimate of the hole capture cross section have been determined as Ev+0.57 eV and $1.9 \times 10^{-15} \mathrm{~cm}^{2}$, respectively. Since the level is only observed in $\mathrm{Mg}$ - 
doped material, it is suggested that the trap can be associated with an $\mathrm{Mg}$ related defect.

\section{Electron-irradiation-induced defects in thick HVPE grown GaN.}

In paper 3-6, intrinsic defects in $2 \mathrm{MeV}$ energy electron irradiated HVPE grown GaN were studied. In Paper 3, low fluence $\left(1 \times 10^{14}\right.$ $\mathrm{cm}^{-2}$ ) irradiated $\mathrm{GaN}$ was investigated. After irradiation, three new electron traps, labeled D1 $\left(\mathrm{E}_{\mathrm{C}}-0.12 \mathrm{eV}\right), \mathrm{D} 5 \mathrm{I}\left(\mathrm{E}_{\mathrm{C}}-0.89 \mathrm{eV}\right)$, and D6 $\left(E_{C}-1.14 \mathrm{eV}\right)$, were observed. Among the three irradiation-induced traps, the trap D1 has previously been reported. The D5I and D6 centers are suggested to be related to primary intrinsic defects due to their high introduction rate and annealing behavior. In paper 4, defects introduced by high fluence $\left(5 \times 10^{16} \mathrm{~cm}^{-2}\right)$ electron irradiation is studied. Four deep trap levels, labelled T1 $\left(\mathrm{E}_{\mathrm{C}}-0.13 \mathrm{eV}\right), \mathrm{T} 2\left(\mathrm{E}_{\mathrm{C}}-\right.$ $0.18 \mathrm{eV}), \mathrm{T} 3\left(\mathrm{E}_{\mathrm{C}}-0.26 \mathrm{eV}\right)$ and $\mathrm{T} 4$ and a broad band of peaks consisting of at least two levels could be observed. These defects, except T1 and T3, were annealed out after annealing at $650 \mathrm{~K}$ for 2 hours. The capture cross section is found to be temperature independent for T2 and T3, while the temperature dependence of T1 suggests that the electron capturing to this level is governed by a cascade capturing process. The annealing behavior of some of the traps induced by high fluence electron irradiation is presented in paper 5. After irradiation, a broad peak, consisting of at least two traps, was detected. The trap D1 $\left(\mathrm{E}_{\mathrm{C}}-0.13 \mathrm{eV}\right)$ observed from the broad peak is formed during the annealing process below $550 \mathrm{~K}$ and completely annealed out at $550 \mathrm{~K}$ after $\sim 10$ hours. The annealing process at 550 $\mathrm{K}$ also forms a new trap D2 $\left(\mathrm{E}_{\mathrm{C}}-0.24 \mathrm{eV}\right)$. From the isothermal annealing study the annihilation activation energy of trap D2 is determined to $1.2 \mathrm{eV}$. The pre-factor suggests that annihilation is governed by a long-range migration process. Finally in paper $\mathbf{6}$, MCTS and DLTS measurements are performed on samples electron irradiated with fluences in the range $1 \times 10^{13} \mathrm{~cm}^{-2}-5 \times 10^{15} \mathrm{~cm}^{-2}$. One hole trap labelled $\mathrm{H} 1\left(\mathrm{EV}_{\mathrm{V}}+0.34 \mathrm{eV}\right.$ was detected already at low fluences and the concentration of $\mathrm{H} 1$ increases with increasing fluences. At fluences higher than $5 \times 10^{14} \mathrm{~cm}^{-2}$, a second hole trap labelled H2 was observed. Simultaneously, the concentration of two electron traps, labelled $\mathrm{T} 1\left(\mathrm{E}_{\mathrm{C}}-0.12 \mathrm{eV}\right)$ and $\mathrm{T} 2\left(\mathrm{E}_{\mathrm{C}}-0.23 \mathrm{eV}\right)$ increases. By studying the increase of the concentration versus electron irradiation fluences, the introduction rate of $\mathrm{T} 1$ and $\mathrm{T} 2 \mathrm{using}$ 
$2 \mathrm{MeV}$-energy electrons was determined to $7 \times 10^{-3} \mathrm{~cm}^{-1}$ and $0.9 \mathrm{~cm}^{-}$ 1 , respectively. Due to the low introduction rate of $\mathrm{T} 1$ and the low threading dislocation density in the HVPE bulk GaN material, it is suggested that the defect is associated with a primary defect decorating extended structural defects. The high introduction rate of the trap H1 suggests that the $\mathrm{H} 1$ defect is associated with a primary intrinsic defect or a complex. 


\section{Bibliography}

[1] H. P. Maruska and J. J. Tietjen, "The preparation and properties of vapordeposited single crystalline GaN," Appl. Phys. Lett., vol. 15, no. 10, p. 327, 1969.

[2] S. P. Denbaars, "Gallium-nitride-based materials for blue to ultraviolet optoelectronics devices," Proc. IEEE, vol. 85, no. 11, pp. 1740-1749, 1997.

[3] S. Nakamura, M. Senoh, S. Nagahama, N. Iwasa, T. Yamada, T. M.Sushita, H. Kiyoku, and Y. Sugimoto, "InGaN-Based Multi-QuantumWell-Structure Laser Diodes.pdf," Jpn. J. Appl. Phys., vol. 35, p. L74, 1996.

[4] S. Nakamura, T. Mukai, and M. Senod, "Candela-class high-brightness InGaN/AlGaN double-heterostructure blue-light-emitting diodes," Appl. Phys. Lett., vol. 64, p. 1687, 1994.

[5] I. Akasaki, "GaN-Based p-n Junction Blue-Light-Emitting Devices," Proc. IEEE, vol. 101, no. 10, pp. 2200-2210, Oct. 2013.

[6] S. Nakamura, M. Senoh, N. Iwasa, S. Nagahama, T. Yamada, and T. Mukai, "Superbright Green InGaN Single-Quantum-Well-Structure LightEmitting Diodes.pdf," Jpn. J. Appl. Phys., vol. 34, pp. L1332-L1335, 1995.

[7] S. J. Pearton, J. C. Zolper, R. J. Shul, and F. Ren, “GaN: Processing, defects, and devices," J. Appl. Phys., vol. 86, no. 1, p. 1, 1999.

[8] Z. M. Zhao, R. L. Jiang, P. Chen, D. J. Xi, Z. Y. Luo, R. Zhang, B. Shen, Z. Z. Chen, and Y. D. Zheng, "Metal-semiconductor-metal GaN ultraviolet photodetectors on $\operatorname{Si}(111)$, , Appl. Phys. Lett., vol. 77, no. 3, p. 444, 2000.

[9] J. C. Carrano, T. Li, D. L. Brown, P. A. Grudowski, C. J. Eiting, R. D. Dupuis, and J. C. Campbell, "Very high-speed metal-semiconductor-metal ultraviolet photodetectors fabricated on GaN," Appl. Phys. Lett., vol. 73, no. 17 , p. 2405, 1998.

[10] D. Walker, E. Monroy, P. Kung, J. Wu, M. Hamilton, F. J. Sanchez, J. Diaz, and M. Razeghi, "High-speed, low-noise metal-semiconductormetal ultraviolet photodetectors based on GaN," Appl. Phys. Lett., vol. 74, no. 5 , p. $762,1999$. 
[11] O. Jani, I. Ferguson, C. Honsberg, and S. Kurtz, "Design and characterization of GaNhGaN solar cells," Appl. Phys. Lett., vol. 91, no. 13, p. 132117, 2007.

[12] D. J. Seo, J. P. Shim, S. B. Choi, T. H. Seo, E. K. Suh, and D. S. Lee, "Efficiency improvement in InGaN-based solar cells by indium tin oxide nano dots covered with ITO films.," Opt. Express, vol. 20, no. S6, pp. A991-A996, Dec. 2012.

[13] R. Horng, S. Lin, Y. Tsai, M. Chu, W. Liao, M. Wu, R. Lin, and Y. Lu, "Improved Conversion Efficiency of GaN/InGaN Thin-Film Solar Cells," IEEE Electron Device Lett., vol. 30, no. 7, pp. 724-726, 2009.

[14] Q. Chen, M. Asif Khan, J. W. Yang, C. J. Sun, M. S. Shur, and H. Park, "High transconductance heterostructure field-effect transistors based on AlGaN/GaN," Appl. Phys. Lett., vol. 69, no. 6, p. 794, 1996.

[15] M. Yanagihara, Y. Uemoto, T. Ueda, T. Tanaka, and D. Ueda, "Recent advances in GaN transistors for future emerging applications," Phys. Status Solidi, vol. 206, no. 6, pp. 1221-1227, Jun. 2009.

[16] B. J. Baliga, "Gallium nitride devices for power electronic applications," Semicond. Sci. Technol., vol. 28, no. 7, p. 074011, Jul. 2013.

[17] T. P. Chow, "High-voltage $\mathrm{SiC}$ and GaN power devices," Microelectron. Eng., vol. 83, no. 1, pp. 112-122, Jan. 2006.

[18] Y. F. Wu, D. Kapolnek, J. P. Ibbetson, P. Parikh, B. P. Keller, and U. K. Mishra, "Very-high power density AlGaN/GaN HEMTs," IEEE Trans. Electron Devices, vol. 48, no. 3, pp. 586-590, Mar. 2001.

[19] T. Uesugi and T. Kachi, "GaN Power Switching Devices for Automotive Applications,” CS MANTECH Conf., no. Paper 2.1, 2009.

[20] X. H. Wu, D. Kapolnek, E. J. Tarsa, B. Heying, S. Keller, B. P. Keller, U. K. Mishra, S. P. DenBaars, and J. S. Speck, "Nucleation layer evolution in metal-organic chemical vapor deposition grown GaN," Appl. Phys. Lett., vol. 68 , no. 10 , p. $1371,1996$.

[21] B. Heying, R. Averbeck, L. F. Chen, E. Haus, H. Riechert, and J. S. Speck, "Control of GaN surface morphologies using plasma-assisted molecular beam epitaxy,” J. Appl. Phys., vol. 88, no. 4, p. 1855, 2000. 
[22] C. Hemmingsson and G. Pozina, "Optimization of low temperature GaN buffer layers for halide vapor phase epitaxy growth of bulk GaN," J. Cryst. Growth, vol. 366, pp. 61-66, Mar. 2013.

[23] C. Hemmingsson, M. Boota, R. Rahmatalla, M. Junaid, G. Pozina, J. Birch, and B. Monemar, "Growth and characterization of thick GaN layers grown by halide vapour phase epitaxy on lattice-matched AlInN templates," $J$. Cryst. Growth, vol. 311, no. 2, pp. 292-297, Jan. 2009.

[24] C. Hemmingsson, P. P. Paskov, G. Pozina, M. Heuken, B. Schineller, and B. Monemar, "Growth of bulk GaN in a vertical hydride vapour phase epitaxy reactor,” Superlattices Microstruct., vol. 40, no. 4-6, pp. 205-213, Oct. 2006.

[25] R. Madar, G. Jacob, J. Hallais, and R. Fruchart, "High pressure solution growth of GaN," J. Cryst. Growth, vol. 31, p. 197, 1975.

[26] S. Porowski, "High pressure growth of GaN - new prospects for blue lasers," J. Cryst. Growth, vol. 166, pp. 583-589, 1996.

[27] H. Yamane, M. Shimada, S. J. Clarke, and F. J. Disalvo, "Preparation of GaN Single Crystals Using a Na Flux,” Chem. Mater., vol. 1896, no. 1, pp. 413-416, 1997.

[28] Y. Mori, M. Imade, M. Maruyama, and M. Yoshimura, "Growth of GaN Crystals by Na Flux Method,” ECS J. Solid State Sci. Technol., vol. 2, no. 8, pp. N3068-N3071, Jul. 2013.

[29] B. Wang and M. J. Callahan, "Ammonothermal Synthesis of III-Nitride Crystals 2006," Cryst. Growth Des., vol. 6, pp. 1227-1246, 2006.

[30] M. E. Levinshtein, S. L. Rumyantsev, and M. S. Shur, Properties of Advanced Semiconductor Materials: GaN, AlN, InN, BN, and SiGe. New York: John Wiley and Sons, 2001.

[31] http://www.ioffe.ru/SVA/NSM/Semicond/Si/index.html.

[32] http://www.ioffe.ru/SVA/NSM/Semicond/GaAs/index.html.

[33] http://www.ioffe.ru/SVA/NSM/Semicond/AlN/index.html.

[34] http://www.ioffe.ru/SVA/NSM/Semicond/InN/index.html.

[35] http://www.ioffe.ru/SVA/NSM/Semicond/SiC/index.html. 
[36] http://www.ioffe.ru/SVA/NSM/Semicond/GaN/index.html.

[37] http://www.ioffe.ru/SVA/NSM/Semicond/Diamond/index.html.

[38] M. Aoki, H. Yamane, M. Shimada, and S. Sarayama, "GaN single crystal growth using high-purity Na as a flux," J. Cryst. Growth, vol. 242, pp. 7076, 2002.

[39] H. Amano, M. Kito, K. Hiramatsu, and I. Akasaki, "P-Type Conduction in Mg-Doped GaN Treated with Low-Energy Electron Beam Irradiation ( LEEBI ),” Jpn. J. Appl. Phys., vol. 28, pp. L2112-L2114, 1989.

[40] S. Fischer, C. Wetzel, E. E. Haller, and B. K. Meyer, "doping in GaNacceptor binding energies," Appl. Phys. Lett., vol. 67, pp. 1298-1300, 1995.

[41] S. Strite and H. Morkoç, "GaN, AlN, and InN: A review," J. Vac. Sci. Technol. B Microelectron. Nanom. Struct., vol. 10, no. 4, p. 1237, Jul. 1992.

[42] W. Götz, N. M. Johnson, J. Walker, D. P. Bour, and R. a. Street, "Activation of acceptors in $\mathrm{Mg}$-doped $\mathrm{GaN}$ grown by metalorganic chemical vapor deposition,” Appl. Phys. Lett., vol. 68, no. 5, p. 667, 1996.

[43] D. Johnstone, S. Doğan, J. Leach, Y. T. Moon, Y. Fu, Y. Hu, and H. Morkoç, "Thermal stability of electron traps in GaN grown by metalorganic chemical vapor deposition," Appl. Phys. Lett., vol. 85, no. 18, p. 4058, 2004.

[44] W. I. Lee, T. C. Huang, J. D. Guo, and M. S. Feng, "Effects of column III alkyl sources on deep levels in $\mathrm{GaN}$ grown by organometallic vapor phase epitaxy," Appl. Phys. Lett., vol. 67, no. 12, p. 1721, 1995.

[45] Y. Tokuda, Y. Matsuoka, H. Ueda, O. Ishiguro, N. Soejima, and T. Kachi, "DLTS study of n-type GaN grown by MOCVD on GaN substrates," Superlattices Microstruct., vol. 40, no. 4-6, pp. 268-273, Oct. 2006.

[46] P. Kamyczek, E. Placzek-Popko, Z. R. Zytkiewicz, E. Zielony, and Z. Gumienny, "Deep traps in n-type GaN epilayers grown by plasma assisted molecular beam epitaxy," J. Appl. Phys., vol. 115, no. 2, p. 023102, Jan. 2014. 
[47] C. D. Wang, L. S. Yu, S. S. Lau, E. T. Yu, and W. Kim, "Deep level defects in n-type GaN grown by molecular beam epitaxy," Appl. Phys. Lett., vol. 72, no. 10, pp. 1211-1213, 1998.

[48] H. Ashraf, M. I. Arshad, S. M. Faraz, Q. Wahab, P. R. Hageman, and M. Asghar, "Study of electric field enhanced emission rates of an electron trap in n-type GaN grown by hydride vapor phase epitaxy," J. Appl. Phys., vol. 108, no. 10, p. 103708, 2010.

[49] P. Hacke, T. Detchprohm, K. Hiramatsu, N. Sawaki, K. Tadatomo, and K. Miyake, "Analysis of deep levels in n-type GaN by transient capacitance methods," J. Appl. Phys., vol. 76, no. 1, p. 304, 1994.

[50] L. Wu, W. E. Meyer, F. D. Auret, and M. Hayes, "Bias-dependent deep level in HVPE n-GaN," Phys. B Condens. Matter, vol. 340-342, pp. 475478, Dec. 2003.

[51] F. D. Auret, S. A. Goodman, F. K. Koschnick, J. M. Spaeth, B. Beaumont, and P. Gibart, "Electrical characterization of two deep electron traps introduced in epitaxially grown $\mathrm{n}-\mathrm{GaN}$ during He-ion irradiation," Appl. Phys. Lett., vol. 73, no. 25, p. 3745, 1998.

[52] F. D. Auret, S. A. Goodman, F. K. Koschnick, J. M. Spaeth, B. Beaumont, and P. Gibart, "Electrical characterization of two deep electron traps introduced in epitaxially grown n-GaN during He-ion irradiation," Appl. Phys. Lett., vol. 73, no. 25, p. 3745, 1998.

[53] V. N. Brudnyi, S. S. Verevkin, A. V. Govorkov, V. S. Ermakov, N. G. Kolin, A. V. Korulin, A. Y. Polyakov, and N. B. Smirnov, "Electronic properties and deep traps in electron-irradiated n-GaN," Semiconductors, vol. 46, no. 4, pp. 433-439, Apr. 2012.

[54] A. Castaldini, A. Cavallini, and L. Polenta, "Deep levels and irradiation effects in n-GaN," J. Phys. Condens. Matter, vol. 12, pp. 10161-10167, 2000 .

[55] S. A. Goodman, F. D. Auret, M. J. Legodi, B. Beaumont, and P. Gibart, "Characterization of electron-irradiated n-GaN," Appl. Phys. Lett., vol. 78, no. 24, p. 3815, 2001.

[56] D. U. Lee, E. K. Kim, B. C. Lee, and D. K. Oh, “Characterization of electron irradiated GaN n+-p diode," Thin Solid Films, vol. 516, no. 11, pp. 3482-3485, Apr. 2008. 
[57] H. Nykänen, S. Suihkonen, L. Kilanski, M. Sopanen, and F. Tuomisto, "Low energy electron beam induced vacancy activation in GaN," Appl. Phys. Lett., vol. 100, no. 12, p. 122105, 2012.

[58] L. Polenta, Z.-Q. Fang, and D. C. Look, "On the main irradiation-induced defect in GaN,” Appl. Phys. Lett., vol. 76, no. 15, p. 2086, 2000.

[59] F. Tuomisto, V. Ranki, D. Look, and G. Farlow, "Introduction and recovery of $\mathrm{Ga}$ and $\mathrm{N}$ sublattice defects in electron-irradiated GaN," Phys. Rev. B, vol. 76, no. 16, p. 165207 , Oct. 2007.

[60] S. A. Goodman, F. D. Auret, G. Myburg, M. . Legodi, P. Gibart, and B. Beaumont, "Deep levels introduced in n-GaN grown by the ELOG technique by high-energy electron irradiation," Mater. Sci. Eng. B, vol. 82, no. 1-3, pp. 95-97, May 2001.

[61] Z. Q. Fang, J. W. Hemsky, D. C. Look, and M. P. Mack, "Electronirradiation-induced deep level in n-type GaN," Appl. Phys. Lett., vol. 72, no. 4 , p. 448, 1998.

[62] H. Nykänen, S. Suihkonen, L. Kilanski, M. Sopanen, and F. Tuomisto, "Low energy electron beam induced vacancy activation in GaN," Appl. Phys. Lett., vol. 100, no. 12, p. 122105, 2012.

[63] A. Y. Polyakov, I. H. Lee, N. B. Smirnov, A. V. Govorkov, E. A. Kozhukhova, N. G. Kolin, A. V. Korulin, V. M. Boiko, and S. J. Pearton, "10 MeV electrons irradiation effects in variously doped n-GaN," J. Appl. Phys., vol. 109, no. 12, p. 123703, 2011.

[64] S. C. Binari, H. B. Dietrich, G. Kelner, L. B. Rowland, K. Doverspike, and D. K. Wickenden, "H, He, and $\mathrm{N}$ implant isolation of n-type GaN," $J$. Appl. Phys., vol. 78, no. 5, p. 3008, 1995.

[65] L. Ha, D. U. Lee, J. S. Kim, E. K. Kim, B. C. Lee, D. K. Oh, S. B. Bae, and K.-S. Lee, "Study on Defect States in GaN Epilayer Induced by Irradiation of High-Energy Electrons," Jpn. J. Appl. Phys., vol. 47, no. 8, pp. 6867-6869, Aug. 2008.

[66] T. Lei, M. Fanciulli, R. J. Molnar, T. D. Moustakas, R. J. Graham, and J. Scanlon, "Epitaxial growth of zinc blende and wurtzitic gallium nitride thin films on (001) silicon," Appl. Phys. Lett., vol. 59, no. 8, p. 944, 1991.

[67] I. Vurgaftman and J. R. Meyer, "Band parameters for nitrogen-containing semiconductors," J. Appl. Phys., vol. 94, no. 6, p. 3675, 2003. 
[68] J. I. Pankove, "Electrolytic Etching of GaN," J. Electrochem. Soc., vol. 119, no. 8, p. $1118,1972$.

[69] C. B. Vartuli, S. J. Pearton, C. R. Abernathy, J. D. MacKenzie, F. Ren, J. C. Zolper, and R. J. Shul, "Wet chemical etching survey of III-nitrides," Solid. State. Electron., vol. 41, no. 12, pp. 1947-1951, 1997.

[70] C. H. Ko, Y. K. Su, S. J. Chang, W. H. Lan, J. Webb, M. C. Tu, and Y. T. Cherng, "Photo-enhanced chemical wet etching of GaN," Mater. Sci. Eng. $B$, vol. 96, no. 1, pp. 43-47, Oct. 2002.

[71] T. L. Chu, “Gallium Nitride Films,” J. Electrochem. Soc., vol. 118, no. 7, p. $1200,1971$.

[72] J. R. Mileham, "Patterning of $\mathrm{AlN}$, InN, and GaN in $\mathrm{KOH}-$ based solutions," J. Vac. Sci. Technol. A Vacuum, Surfaces, Film., vol. 14, no. 3, p. 836, May 1996.

[73] D. Zhuang and J. H. Edgar, "Wet etching of GaN, AlN, and SiC: a review," Mater. Sci. Eng. R Reports, vol. 48, no. 1, pp. 1-46, Jan. 2005.

[74] H. Morkoç, "General Properties of Nitrides," in Handbook of nitride semiconductors and devices. Vol 1., vol. 1, 2008, pp. 1-129.

[75] T. Palacios, F. Calle, M. Varela, C. Ballesteros, E. Monroy, F. B. Naranjo, M. A. Sánchez-García, E. Calleja, and E. Muñoz, "Wet etching of GaN grown by molecular beam epitaxy on Si(111)," Semicond. Sci. Technol., vol. 15, no. 10, pp. 996-1000, Oct. 2000.

[76] D. A. Stocker, E. F. Schubert, and J. M. Redwing, "Crystallographic wet chemical etching of GaN," Appl. Phys. Lett., vol. 73, no. 18, p. 2654, 1998.

[77] A. Shintani and S. Minagawa, "Etching of GaN Using Phosphoric Acid," J. Electrochem. Soc., vol. 123, pp. 706-713, 1976.

[78] H. Amano, N. Sawaki, I. Akasaki, and Y. Toyoda, "Metalorganic vapor phase epitaxial growth of a high quality GaN film using an AlN buffer layer," Appl. Phys. Lett., vol. 48, no. 5, p. 353, 1986.

[79] B. Łucznik, B. Pastuszka, I. Grzegory, M. Boćkowski, G. Kamler, E. Litwin-Staszewska, and S. Porowski, "Deposition of thick GaN layers by HVPE on the pressure grown GaN substrates," J. Cryst. Growth, vol. 281, no. 1, pp. 38-46, Jul. 2005. 
[80] G. Nataf, B. Beaumont, A. Bouillé, P. Gibart, S. Haffouz, and M. Vaille, "Lateral overgrowth of high quality $\mathrm{GaN}$ layers on $\mathrm{GaN} / \mathrm{Al}_{2} \mathrm{O}_{3}$ patterned substrates by halide vapour-phase epitaxy," J. Cryst. Growth, vol. 192, pp. 73-78, 1998.

[81] C. Hemmingsson, B. Monemar, Y. Kumagai, and A. Koukitu, "Growth of III-Nitrides with Halide Vapor Phase Epitaxy (HVPE)," in Springer Handbook of Crystal Growth, vol. 2, no. 1, 2010, pp. 869-896.

[82] V. S. Ban, "Mass spectrometric and thermodynamic studies of the CVD of some III-V compounds,” J. Cryst. Growth, vol. 17, pp. 19-30, 1972.

[83] P. A. Denis and K. Balasubramanian, "Spectroscopic constants and potential energy curves of gallium nitride $(\mathrm{GaN})$ and ions: $\mathrm{GaN}+$ and GaN-," Chem. Phys. Lett., vol. 423, no. 1-3, pp. 247-253, May 2006.

[84] D. Tzeli and A. A. Tsekouras, "The electron affinity of gallium nitride $(\mathrm{GaN})$ and digallium nitride (GaNGa): the importance of the basis set superposition error in strongly bound systems.," J. Chem. Phys., vol. 128, no. 14, p. 144103, Apr. 2008.

[85] A. C. Schmitz, A. T. Ping, M. A. Khan, Q. Chen, J. W. Yang, and I. Adesida, "Schottky barrier properties of various metals on n-type GaN," Semicond. Sci. Technol., vol. 11, no. 10, pp. 1464-1467, Oct. 1996.

[86] A. C. Schmitz, A. T. Ping, M. A. Khan, Q. Chen, J. W. Yang, and I. Adesida, "Metal Contacts to n-Type GaN," J. Electron. Mater., vol. 27, pp. 255-260, 1998.

[87] D. R. Lide, CRC Handbook of Chemistry and Physics, Internet Version 2005, <http://www.hbcpnetbase.com>. 2005.

[88] V. Zeghbroeck, Principles of Semiconductor Devices. 2004.

[89] S. M. Sze and K. K. Ng, Physics of semiconductor devices. 2006.

[90] M. O. Alade, "High Temperature Electronic Properties of a Microwave Frequency Sensor - GaN Schottky Diode," Adv. Phys. Theor. Appl., vol. 15, pp. 47-53, 2013.

[91] P. Blood and J. W. Orton, The Electrical Characterization of Semiconductors: Majority Carriers and Electron States. Academic Press, 1992. 
[92] C. G. Van de Walle, "First-principles calculations for defects and impurities: Applications to III-nitrides," J. Appl. Phys., vol. 95, no. 8, p. 3851, 2004.

[93] H. T. Nykänen, "Low energy electron beam irradiation of gallium nitride," Aalto University, 2013.

[94] R. N. Hall, "Electron-Hole Recombination in Germanium," Phys. Rev., vol. 87, p. 387, 1952.

[95] W. Shockley and W. T. Read, "Statistics of the Recombinations of Holes and Electrons," Phys. Rev., vol. 87, pp. 835-842, 1952.

[96] C. Kittel, "Semiconductor crystals," in Introduction of Solid State Physics, John Wiley \& Sons, 2005, p. 206.

[97] J. Frenkel, "On pre-breakdown phenomena in insulators and electronic semi-conductors," Phys. Rev., vol. 54, pp. 647-648, 1938.

[98] E. N. Korol', "IONIZATION OF IMPURITY STATES IN SEMICONDUCTORS BY AN ELECTRIC FIELD," Sov Phys Solid State, vol. 19 , no. 8, pp. 1327-1330, 1977.

[99] S. Ganichev, E. Ziemann, W. Prettl, I. Yassievich, A. Istratov, and E. Weber, "Distinction between the Poole-Frenkel and tunneling models of electric-field-stimulated carrier emission from deep levels in semiconductors," Phys. Rev. B, vol. 61, no. 15, pp. 10361-10365, Apr. 2000 .

[100] P. A. Martin, B. G. Streetman, and K. Hess, "Electric Field Enhanced Emission From Non-Coulombic Traps in Semiconductors.," J. Appl. Phys., vol. 52, no. 1981, pp. 7409-7415, 1981.

[101] A. O. Evwaraye, S. R. Smith, W. C. Mitchel, and G. C. Farlow, "Electric field enhancement of electron emission rates from $Z$ [sub 1/2] centers in 4H-SiC,” J. Appl. Phys., vol. 106, no. 6, p. 063702, 2009.

[102] A. K. Jonscher, "Electronic properties of amorphous dielectric films," Thin Solid Films, vol. 1, no. 3, pp. 213-234, 1967.

[103] J. L. Hartke, "The three-dimensional poole-frenkel effect," J. Appl. Phys., vol. 39, no. 1968, pp. 4871-4873, 1968. 
[104] A. Dadgar, D. Ammerlahn, A. Näser, R. Heitz, M. Kuttler, D. Bimberg, N. Baber, J. Hyeon, and H. Schumann, "Deep-level transient-spectroscopy study of rhodium in indium phosphide," Phys. Rev. B, vol. 53, no. 11, pp. 7190-7196, 1996.

[105] N. Baber, H. Scheffler, A. Ostmann, T. Wolf, and D. Bimberg, "Field effect on electron emission from the deep Ti donor level in InP," Phys. Rev. B, vol. 45, no. 8, pp. 4043-4047, 1992.

[106] G. Vincent, A. Chantre, and D. Bois, "Electric field effect on the thermal emission of traps in semiconductor junctions," J. Appl. Phys., vol. 50, no. 1979, pp. 5484-5487, 1979.

[107] S. Makram-Ebeid and M. Lannoo, "Electric-Field-Induced PhononAssisted Tunnel Ionization from Deep Levels in Semiconductors," Phys. Rev. Lett., vol. 48, no. 18, pp. 1281-1284, 1982.

[108] M. Lax, "Cascade capture of electrons in solids," Phys. Rev., vol. 119, pp. 1502-1523, 1960.

[109] C. H. Henry and D. V. Lang, "Nonradiative capture and recombination by multiphonon emission in GaAs and GaP," Phys. Rev. B, vol. 15, pp. 9891016, 1977.

[110] A. Haug, "Band-to-band auger recombination in semiconductors," J. Phys. Chem. Solids, vol. 49, no. 6, pp. 599-605, 1988.

[111] D. K. Schroder, Semiconductor material and device characterization. New Jersey: John Wiley \& Sons, 2006.

[112] D. V. Lang, "Deep level transient spectroscopy: A new method to characterize traps in semiconductors.pdf," J. Appl. Phys., vol. 45, p. 3023, 1974.

[113] J. Criado, A. Gomez, E. Calleja, and E. Muñoz, "Novel method to determine capture crosssection activation energies by deeplevel transient spectroscopy techniques," Appl. Phys. Lett., vol. 52, p. 660, 1988.

[114] T. T. Duc, G. Pozina, E. Janzén, and C. Hemmingsson, "Investigation of deep levels in bulk GaN material grown by halide vapor phase epitaxy," $J$. Appl. Phys., vol. 114, no. 15, p. 153702, 2013.

[115] E. PŁaczek-Popko, J. Trzmiel, E. Zielony, S. Grzanka, R. Czernecki, and T. Suski, "Deep level transient spectroscopy signatures of majority traps in 
GaN p-n diodes grown by metal-organic vapor-phase epitaxy technique on GaN substrates," Phys. B Condens. Matter, vol. 404, no. 23-24, pp. 48894891, Dec. 2009.

[116] D. Pons, "Accurate determination of the free carrier capture kinetics of deep traps by space-charge methods," J. Appl. Phys., vol. 55, no. 10, p. 3644, 1984.

[117] T. Wosiński, "Evidence for the electron traps at dislocations in GaAs crystals," J. Appl. Phys., vol. 65, no. 4, p. 1566, 1989.

[118] S. D. Brotherton, "The width of the non-steady state transition region in deep level impurity measurements," Solid. State. Electron., vol. 26, no. 10, pp. 987-990, Oct. 1983.

[119] D. V. Lang, Topics in Applied Physics. Berlin: Springer, 1979.

[120] H. Lefèvre and M. Schulz, "Double Correlation Technique (DDLTS) for the Analysis of Deep Level Profiles in Semiconductors," Appl. Phys., vol. 12, pp. 45-53, 1977.

[121] M. C. Chen, D. V. Lang, W. C. Dautremont-Smith, a. M. Sergent, and J. P. Harbison, "Effects of leakage current on deep level transient spectroscopy," Appl. Phys. Lett., vol. 44, no. 8, p. 790, 1984.

[122] R. Brunwin, B. Hamilton, P. Jordan, and A. R. Peaker, "Detection of minority-carrier traps using transient spectroscopy," Electron. Lett., vol. 15, pp. 349-350, 1979.

[123] http://www.tf.uni-kiel.de/matwis/amat/def_en/.

[124] C. B. Franziska, “Deep levels in SiC,” Linköping University, 2011.

[125] C. Hemmingsson, "Deep Levels in Electron-Irradiated and As-grown SiC Power Devices Material,” Linköping University, 1998. 



\section{Papers}

The articles associated with this thesis have been removed for copyright reasons. For more details about these see:

http://urn.kb.se/resolve?urn=urn:nbn:se:liu:diva-121710 